PRZEGLĄD NAUK HISTORYCZNYCH 2019, R. XVIII, NR 1

http://dx.doi.org/10.18778/1644-857X.18.01.02

JarosłaW Pietrzak

Uniwersytet Pedagogiczny w KRAKOWie*

iD https://orcid.org/0000-0003-0341-2273

\title{
Sznur w heraldyce królowej wdowy Marii Kazimiery d'Arquien Sobieskiej
}

Streszczenie. Praca, o tematyce heraldyczno-genealogicznej, dotyczy pomijanego w dotychczasowych badaniach elementu w herbie królowej wdowy Marii Kazimiery d'Arquien Sobieskiej, jakim był sznur. W pierwszej części omówione zostały tradycje jego stosowalności sięgające XV w. i kręgu dworu książąt bretońskich. Ukazano także zadomowienie się owej tradycji w heraldyce dynastii kapetyńskiej i jej dwóch gałęzi: Walezjuszy i Burbonów. Przedstawiono proces, wedle którego sznur od osobistego emblematu związanego $z$ domem panującym w Bretanii przekształcił się w element symbolizujacy wdowieństwo królowych Francji. Następnie w XVII w. wszedł on do symboliki wdów ze sfery arystokratycznej. Podano tu argumenty heraldyki eksponowanej na pieczęciach, medalach, grafice portretowej i przedmiotach codziennego użytku, m.in. książkach. W drugiej części zastanowiono się nad przyczynami dołączenia przez królową Marię Kazimierę d'Arquien Sobieska symbolu sznura. Uznano jej działanie za świadoma kreację, zmierzającą do wywyższenia swego majestatu po 1696 r. i podkreślenia relacji $z$ domem panującym we Francji.

Słowa kluczowe: heraldyka, wdowieństwo, Sobiescy, Francja.

I

ntrygującym elementem herbu wdowiego królowej Marii Kazimiery d'Arquien Sobieskiej jest okalający tarczę sznur złożony z ośmiu węzłów. Jego pierwowzoru $z$ cała pewnością szukać należy w formie białego sznura franciszkańskiego (tzw. cingulum) o trzech węzłach oznaczajacych trzy śluby zakonne: życie w posłuszeństwie, bez własności i w czystości ${ }^{1}$.

* Instytut Historii i Archiwistyki, Katedra Historii Nowożytnej, e-mail: jaroslawpietrzak777@gmail.com.

${ }^{1}$ Szerzej na ten temat: P. Gach, Habity zakonne $w$ średniowieczu. Zarys problematyki, [w:] Klasztor w kulturze średniowiecznej Polski, red. A. Pobóg-Lenarto- 
Informację o sznurze jako pierwszy podał w 1883 r. Józef Łoski, przy okazji opisywania autografów i pamiątek znajdujących się w posiadaniu rodu Ciecierskich w Bacikach ${ }^{2}$. Ten nietypowy dla polskiej heraldyki element został błędnie zidentyfikowany jako sznur splecionych pereł $^{3}$. Przyglądajac się heraldyce królowej Marii Kazimiery d'Arquien Sobieskiej po 1696 r., tj. po śmierci Jana III, można dojść do wniosku, że sznur oplatający pięciopolową tarczę herbową ${ }^{4}$ występował nader często. Pojawił się on na zachowanych w dobrym stanie odciskach pieczęci monarchini $z$ lat $1704^{5}, 1705^{6}, 1707^{7}, 1714^{8}$ i $1715^{9}$,

wicz, M. Derwich, Opole 1995, s. 491-516; E. Kapellari, Święte znaki w liturgii i codzienności, Kraków 2002, s. 57; L. Rotter, Habit franciszkański na przykładzie wybranych wspólnot męskich i żeńskich, „Zeszyty Sądecko-Spiskie” 2009, t. IV, s. 66-73.

2 J. Ło ski, Jan Sobieski, jego rodzina, towarzysze broni i współczesne zabyt$k i$, Warszawa 1883, s. 127. Dokumenty królewskie z marmurowym popiersiem króla, szachownica oraz hebanowym klęcznikiem królowej zostały ofiarowane damie dworu królowej Marii Kazimiery Barbarze $z$ Ossolińskich $1^{\circ} \mathrm{v}$. Ciecierskiej $2^{\circ}$ v. Oborskiej, córce starosty drohickiego i chorażego mielnickiego Jakuba Ossolińskiego oraz Zofii Teresy z Chrzastowa Zabłockiej. Przed druga wojną światowa pamiatki przechowywane były w dworach Ciecierskich w Ostrożanach i Bacikach. W 1933 r. niektóre $z$ pamiątek wypożyczone zostały Muzeum Narodowemu w Warszawie na prawach wieczystego depozytu i pozostają tam do dziś. Z kolei dokumenty zdeponowane sa w archiwum Muzeum Rolnictwa im. K. Kluka w Ciechanowcu. Vide: H. Cieciers ki, Pamiętniki, wyd. T. Ciecierska-Chłapowa, Warszawa 2013, s. 21-22; N. To mas zews ki, O. To mas zew ska, Dokumenty zwiazane ze szlachta w zbiorach Muzeum Rolnictwa im. Ks. Krzysztofa Kluka w Ciechanowcu. „Ciechanowiecki Rocznik Muzealny” 2007, t. III, s. 25-26.

${ }^{3}$ Sigilla Regum et Reginarum Poloniae. Pieczęcie królów i królowych polskich ze zbiorów Archiwum Głównego Akt Dawnych, wyd. Archiwum Główne Akt Dawnych i Naczelna Dyrekcja Archiwów Państwowych, Warszawa 2015, s. 179.

${ }^{4} \mathrm{~W}$ polu pierwszym i trzecim umieszczono herb Orzeł Biały, w polu drugim i czwartym herb Pogoń Litewska, a w tarczy sercowej dwudzielnej w słup herb Janina Sobieskich i herb rodu d'Arquien.

${ }^{5}$ M.K. d'Arquien Sobieska do Mikołaja Kroguleckiego, Rome 16 II 1704, Archiwum Główne Akt Dawnych w Warszawie, Zbiory Muzeum Narodowego w Warszawie [dalej: AGAD, ZMN], sygn. 446, s. 2.

${ }^{6}$ M.K. d'Arquien Sobieska do M. Kroguleckiego, Rome 23 XI 1705, Biblioteka Ksiażąt Czartoryskich w Krakowie [dalej: BCz.], sygn. 5885/III, list nr 24282.

7 M.K. d'Arquien Sobieska do Klemensa XI, Rome 30 V 1707, British Library w Londynie, sygn. Ms. Add. 8526; eadem do Stanisława Antoniego Szczuki, [b.m.] 16 IV 1707, Archiwum Narodowe w Krakowie, Zbiory Rusieckich, sygn. 60, k. 25v.

${ }^{8}$ M.K. d'Arquien Sobieska do Aleksandra Pleszewskiego, Blois 7 IV 1714, AGAD, Archiwum Warszawskie Radziwiłłów, sygn. 33, s. 42; eadem do N.N., Blois 17 XII 1714, BCz., sygn. 2190/IV, list nr 24276.

${ }^{9}$ M.K. d'Arquien Sobieska do Lorenzo Antonio Sardi, Blois 15 III 1715, Archivio di Stato di Lucca, Archivio Sardi, nr 145, list nr 56. 
w uroczystym dyplomie królowej wydanym w 1702 r. dla architekta Tomasza Mattei, zaświadczającym o jego zdolnościach w zakresie budownictwa i zdobnictwa oraz wierności względem zleceniodawczyni w pełnionej przez niego funkcji nadwornego architekta ${ }^{10}$, $\mathrm{w}$ grafice portretowej królowej opatrzonej jej herbem ${ }^{11}$ oraz w herbie królowej umieszczonym w portalu wejścia głównego do jej rzymskiej rezydencji Palazzo Zuccari. Wszystkie wymienione wyobrażenia zawieraja sznur nawiązujacy do heraldyki francuskiej, w której znany jest pod nazwa la cordelière. Nie można jednak powiedzieć, by element ten stosowany był przez królową systematycznie. Znane są nam $z$ czasów jej wdowieństwa co najmniej dwie pieczęcie odciśnięte przez papier, ukazujące dwie złączone ze sobą tarcze pięciopolowe zwieńczone korona królewska i ujęte palmowymi liśćmi ${ }^{12}$ oraz jedna pieczęć sygnetowa wyciśnięta na czarnym la$\mathrm{ku}$, ukazująca tarczę dwudzielną w słup $z$ herbem Janina i rodu d'Arquien, podobnie ujęta liśćmi palmy ${ }^{13}$, symbolizującymi splendor i dostojeństwo władzy. Na obecnym etapie badania trudno jednoznacznie orzec, od czego zależała stosowalność różnych od siebie przedstawień heraldycznych ${ }^{14}$. Celem opracowania jest przedstawienie genezy i występowania sznura w heraldyce francuskiej oraz próba wyjaśnienia powodów jego włączenia do herbu wdowiego królowej Marii Kazimiery d'Arquien Sobieskiej.

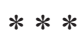

${ }_{10}$ Zamek Królewski w Warszawie - Muzeum, Zbiory Tomasza Niewodniczańskiego, sygn. H 25, poz. 4.

${ }^{11}$ A. Bas s a ni, Viaggio a Roma della [...] Maria Casimira regina di Polonia vedoua [...] delle [...] Giovanni III per il voto di visitare i Luoghi Santi et il supremo Pastor della Chiesa Innocenzo XII. All' [...] Cardinale Barberino protettore di quel regno. Del Con. Antonio Bassani Padovano Can. di Varmia, Roma 1700; H. Wi da cka, Zagadki portretu królowej Marii Kazimiery w diariuszu Antonia Bassaniego, „Studia Wilanowskie” 2009, t. XVI, s. 108-113.

${ }^{12}$ M.K. d'Arquien Sobieska do Elżbiety z Lubomirskich Sieniawskiej, Rome 1 VIII 1706, AGAD, ZMN, sygn. 30, s. 57-58.

${ }_{13}$ M.K. d'Arquien Sobieska do Bartłomieja Sardi, [b.m.] 31 V [1697?], Archivio Storico Capitolino w Rzymie, Archivio Capranica-Scarlatti [dalej: ASCap., ACS], vol. MCLXXXI.

${ }^{14}$ Dodajmy jednak, że oba elementy, tj. sznur i palmy, mogły występować jednocześnie, jak działo się to w przypadku herbu opactwa Notre-Dame-de-Jouarre w Jouarre koło Rouen we Francji. Vide: http://patrimoine-de-france.com/seine-et-marne/jouarre/abbaye-notre-dame-de-jouarre-1.php (dostęp: 14 III 2017). 
Rozważając początki wykorzystania sznura w heraldyce francuskiej, należy cofnać się do XV w., by prześledzić heraldykę książąt i księżnych Bretanii $z$ rodu Montfort. Po pierwsze, należy wspomnieć, że dwory ostatnich przedstawicieli tego rodu stanowiły bardzo ważne miejsce kształtowania się kultury rycerskiej ${ }^{15}$. W 1445 r. książę Franciszek II ustanowił Zakon Kłosa (l'Ordre d’Epy), konsolidujący możnych, wiernych książętom bretońskim i dynastii Montfort $^{16}$. Zakon ten funkcjonował obok istniejacego już od $1381 \mathrm{r}$. Zakonu Gronostaja (l'Ordre de l'Hermine) powołanego przez księcia Jana IV. W wyglądzie obu insygniów orderowych już w XV w. pojawił się sznur tworzacy kompozycje $z$ emblematami, osobno kłosem lub symbolicznym przetworzeniem szaty gronostajowej. $\mathrm{W}$ takich formach zostały one zaznaczone na nagrobkach Franciszka II i jego drugiej żony Małgorzaty $z$ Foix w katedrze w Nantes ${ }^{17}$. Obecność sznura tłumaczyć należy głębszymi niż tylko kulturowe przesłankami. Wpływ na jego pojawienie się w symbolice książęcej miał niewątpliwie kult św. Franciszka $z$ Asyżu, upowszechniony $\mathrm{w}$ Bretanii za sprawą dwóch ostatnich książąt $z$ dynastii Montfort - Franciszka I (1427-1450) i Franciszka II (1435-1488). Około 1449 r. sprowadzono franciszkanów obserwantów, choć pierwotnie zakon ten miał już $\mathrm{w}$ Bretanii swoje placówki ${ }^{18}$. W latach pięćdziesiatych XV w. symbol sznura został spopularyzowany w kręgu bretońskiej rodziny książęcej. Z czasem włączono go do herbów

15 J. Brejon de la Vergnee, L'emblématique d'Anne de Bretagne d'après les manuscrits à peinture, „Mémoires de la Société d'Histoire et d'Archéologie de Bretagne" 1978, t. LV, s. 83-97; A.-M. Le co qe, François I'r. Imaginaire, symbolique et politique à l'aube de la Renaissance française, Paris 1987; C. de Merindol, Essai sur l'emblématique et la thématique de la maison de Bretagne. Mise au point, nouvelles lectures, nouvelles perspectives, [w:] 1491. La Bretagne, terre d'Europe, publ. J. Kerhervé, T. Daniel, Brest-Quimper 1992, s. 265-294; P. Tourault, Les ducs et duchesses de Bretagne, $X^{e}-X V I^{e}$ siècle, Paris 2009, s. 293-297.

${ }^{16}$ M. Jones, Les signes du pouvoir. L'ordre de l'Hermine, les devises et les hérauts des ducs de Bretagne au XVe siècle, "Mémoires de la Société d'histoire et d'archéologie de Bretagne" 1991, t. LXVIII, s. 141-173.

${ }^{17}$ L. Hablot, Pour en finir ou pour commencer! - avec l'ordre de la Cordelière, [w:] Pour en finir avec Anne de Bretagne, ed. D. Le Page, Nantes 2004, s. 70-73.

${ }_{18}$ Franciszkanie przybyli do Nantes w 1253 r. za sprawa rodziny de Rieux i księcia Jana I z dynastii Dreux. W 1449 r. Franciszek I, za radą Henryka Tudora hr. Richmond (późniejszego Henryka VII), sprowadził braci z zakonu franciszkanów zwanych obserwantami. Vide: V.K. Henders on, Rethinking Henry VII: The Man and His Piety in the Context of the Observant Franciscans, [w:] Reputation and Representation in Fifteenth-Century Europe, eds D.L. Biggs, S.D. Michalove, Leiden 2004, s. 323-324. 


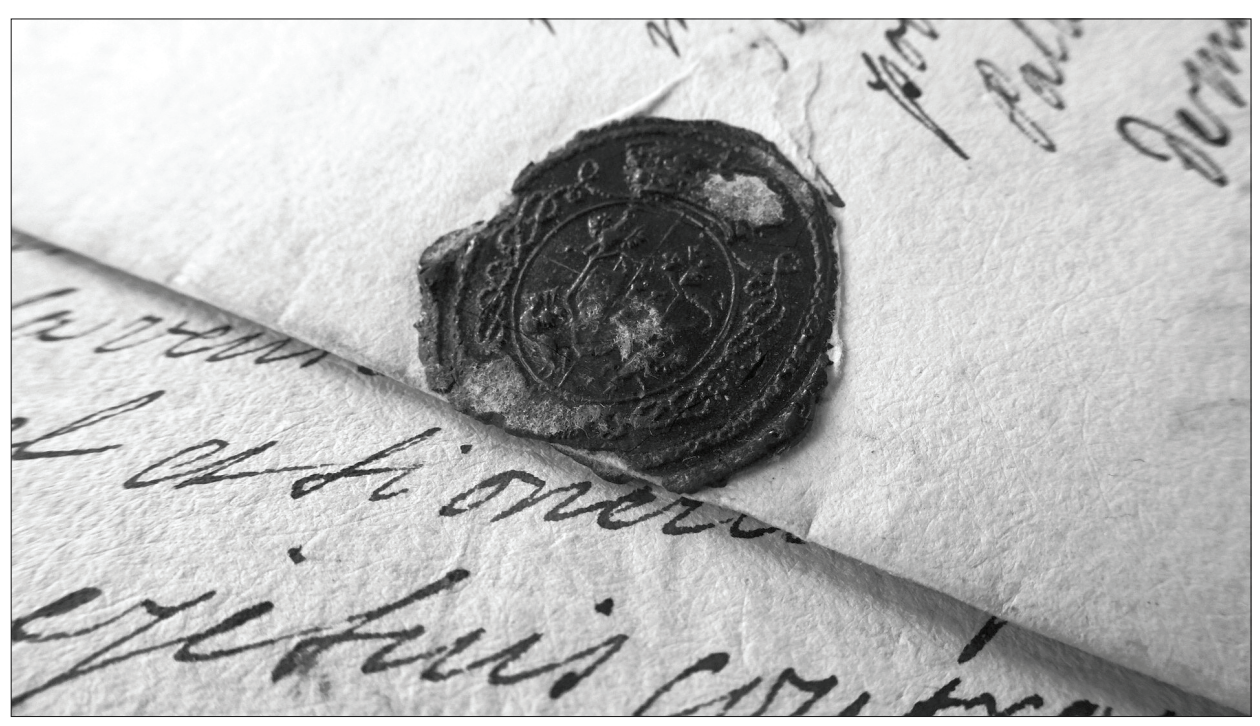

1. Pieczęć Marii Kazimiery d'Arquien Sobieskiej w liście do nieznanego adresata, Blois 17 XII 1714, Biblioteka Książąt Czartoryskich w Krakowie sygn. 2190/IV, list nr 24276

księżnych, m.in. Izabeli Stuart (1425 lub 1427-1494), żony Franciszka I, Franciszki z Amboise (1427-1485), żony Piotra II, oraz Małgorzaty Bretońskiej (1443-1469) i Małgorzaty z Foix (po 1458-1486) - dwóch żon Franciszka II ${ }^{19}$. Sznur zaczął też występować na monetach bretońskich w latach 1458-1488 i w wystroju rzeźbiarskim katedry św. św. Piotra i Pawła w Nantes oraz kościoła w Fougères ${ }^{20}$. Dodajmy tylko, że obaj władcy: Franciszek I i Franciszek II przedstawiani byli za pośrednictwem sztuk plastycznych w pozie orantów $z$ towarzyszącym im świętym patronem ${ }^{21}$.

Począwszy od 1378 r., kiedy parlament paryski i izba parów wobec nielojalności ówczesnego księcia Jana IV zaaprobowały zajęcie jego władztwa przez konfiskatę królewską, następowało stopniowe uzależnienie Bretanii od Francji ${ }^{22}$. Tendencjom tym przeciwdziałał Franciszek II, odmawiając królowi Francji złożenia hołdu

\footnotetext{
${ }^{19}$ L. Hablot, Pour en finir..., s. 49-52.

20 Ibidem, s. 53.

${ }^{21}$ Za przykład wskazać tu można iluminacje modlitewnika Franciszka I wykonanego w latach 1460-1465. Vide: Bibliothèque nationale de France [dalej: BnF] Ms. Lat. 1369, f. 56v; M.-H. Santrot, Entre France et Angleterre, le duché de Bretagne, essai d'iconographie des ducs de Bretagne, Nantes 1988, s. 251-254.

${ }^{22}$ P. Tourault, Les ducs..., s. 257-258.
} 
lennego oraz kilkukrotnie angażując się w wystapienia przeciwko Ludwikowi XI i Karolowi VIII. Śmierć Franciszka w 1488 r. bez pozostawienia męskiego potomka spowodowała przekazanie władzy - zgodnie $z$ wcześniejszymi decyzjami stanów księstwa w Vannes w 1486 r. - w ręce jego najstarszej córki Anny. Stając się najlepszą partią małżeńską w całej Europie, Anna zyskała liczne propozycje wyjścia za mąż ze strony m.in. króla Anglii Henryka VII Tudora, króla niemieckiego i spadkobiercy dynastii burgundzkiej Maksymiliana Habsburga, księcia orleańskiego Ludwika i Jana de Chalon, księcia Oranii. Wybór Anny w 1490 r. padł na króla rzymskiego Maksymiliana i wkrótce doszło do zawarcia ślubu per procura. Na taką decyzję nie wyraził jednak zgody król Francji Karol VIII, który ruszył $z$ wyprawą zbrojna na Bretanię. W $1491 \mathrm{r}$. wojska francuskie zdobyły Rennes, a król zmusił Annę do zmiany decyzji i sam ja poślubił ${ }^{23}$. W traktacie zawartym w Langeais w grudniu 1491 r. uzgodniono także dożywotnie prawa króla Francji do tytułu i ziem księstwa Bretanii. Kilka lat po jego śmierci w 1498 r. wszystkie prawa do księstwa powróciły do Anny, która restytuowała główne instytucje władzy nad księstwem. W 1499 r. Anna poślubiła kuzyna Karola VIII - Ludwika ks. Orleańskiego, panującego w latach 1498-1515 pod imieniem Ludwika XII. Król uzyskał tylko tytuł księcia małżonka w Bretanii, a prawa do księstwa w przyszłości miały przejść na drugie w kolejności dziecko pary, niezależnie od płci24.

Koronacja i okres pierwszego wdowieństwa Anny zaowocowały ważnym zjawiskiem w sferze heraldyczno-emblematycznej. Między 1491 a 1498 r. królowa dołączyła do swego herbu królewskiego sznur, zaczerpnięty $z$ tradycji bretońskiej25. Element ten wraz $z$ monogramem imienia władczyni stał się $z$ czasem emble-

${ }^{23}$ Y. Labande-Mailfert, Le mariage d'Anne de Bretagne avec Charles VIII, vu par Erasme Brasca, „Mémoires de la Société d'histoire et d'archéologie de Bretagne" 1978, t. LV, s. 17-42; P. Tourault, Anne de Bretagne, Paris 2014; id e m, Les ducs..., s. 343-358.

${ }^{24}$ A. Dupuy, Histoire de l'Union de la Bretagne à la France, Paris 1880, s. 447-501; M. Nassiet, D. La Page, L'union de la Bretagne à la France, Morlaix 2003, s. 150-174.

${ }^{25}$ Archives nationales de France - site de Paris, Centre de sigillographie et d'héraldique [dalej: AnF Centre], Sceau d'Anne de Bretagne, sygn. D-48, St-4395 ${ }^{\text {bis; }}$ Deux planches sur bois, représentant les armoiries de France et de Bretagne accouplées, BnF, Département éstampes et photographie [dalej: Dép. éstampes], FOL-QB-201; L. Hablot, Pour..., s. 53-54. 
matem oznaczającym królową ${ }^{26}$, w odróżnieniu od jelenia, jednorożca lub krzyża jerozolimskiego - emblematów Karola VIII i jeżozwierza symbolizującego Ludwika XII ${ }^{27}$. Sznur (la cordelière) nabrał znaczenia symbolu wyrażającego zwierzchność Anny nad jej bretońskim władztwem ${ }^{28}$. Właścicielka chciała wskazać na swe pochodzenie $z$ dynastii Monfort oraz podkreślić legalność i niezbywalność swych praw do Bretanii, zarówno wobec obu mężów, jak i względem pretendentów do tronu bretońskiego $\mathrm{z}$ rodów de Rohan, de Penthièvre, de Rieux i de Châtillon-Brosse. Anna eksponowała sznur nie tylko na pieczęciach, lecz także na monetach, medalach, biżuterii oraz w elementach wystroju wnętrz, jak tapiserie ścienne ${ }^{29}$. Zauważyć zatem należy, że sznur, obecny początkowo w heraldyce bretonskiej, w początku XVI w. przeniknał za sprawą Anny Bretońskiej do heraldyki francuskiej.

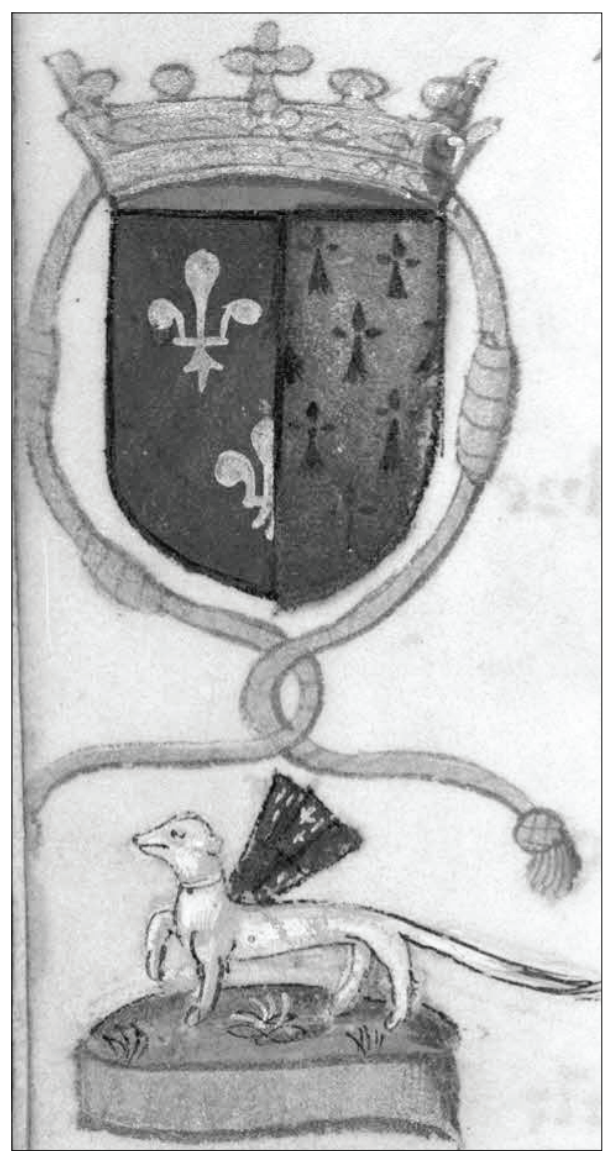

2. Herb Anny Bretońskiej ze sznurem wdowim, Bibliothèque de Rennes Ms 0332, f. 56v

${ }^{26}$ Chronique universelle de Jean de Courcy, dite Bouquechardière, livres IV-VI, BnF, Français 15459, f. 3r., 11v, 19v, 25v, 33v, 108v.

${ }_{27}$ J.O. Dele pi er re, Notice sur la cheminée de la salle des magistrats du Francs de Bruges, Bruges 1841, s. 9-10; N. Hochner, Louis XII and the porcupine: transformations of a royal emblem, „Rennaisance Studies” 2001, vol. XV, no. 1, s. 17-36.

${ }^{28} \mathrm{~L}$. Hablot, Les princesses et la devise. L'utilisation politique des devises et des ordres de chevalerie par les femmes de pouvoir à la fin du Moyen Age, [w:] Femmes de pouvoir et pouvoir de femmes dans l'Occident, eds A. Nayt-Dubois, E. Satninelli-Foltz, Valenciennes 2009, s. 163-176.

29 „Extraits de divers ouvrages, chroniques et memoires... de la Bibliotheque de Maison Gothique”, BCz., sygn. 6770, t. II, s. 205-206; L. Hablot, Pour..., s. 52; C.J. B rown, The Queen's Library. Image-Making at the Court of Anne of Brittany, 1477-1514, Philadelphie-Oxford 2011, s. 63-108. 
Symbolika sznura miała o wiele głębsze znaczenie, nieograniczające swego rozumienia do spraw sukcesyjnych. Sznur, jako część habitu mniszego, oznaczał ubóstwo i reprezentował sferę rygorystycznej dewocji rozwijanej w duchu pasyjnym i chrystologicznym. Wskażmy, że sznur, którym przywiązano Chrystusa do kolumny biczowania, stał się jednym $z$ eksponowanych $\mathrm{w}$ malarstwie, grafice i rzeźbie tzw. Arma Christi, czyli narzędziem Męki Pańskiej. Ponadto, w końcu epoki średniowiecza, stał się symbolem dziewictwa i cnoty czystości uosabianych przez Matkę Bożą ${ }^{30}$. W tym kontekście należy rozpatrywać eksponowanie sznura otaczającego herb królowej na iluminowanych stronach zbioru jej godzinek „Les Grandes Heures d'Anne de Bretagne" (1503-1508) ${ }^{31}$ oraz na ilustracjach $z$ cyklu "Commémoration de la mort d'Anne de Bretagne” $(1514)^{32}$, autorstwa Jana Coene'a IV zw. Mistrzem Wjazdów Paryskich lub Mistrzem Wjazdów Paryskich Królowych Francji.

Pojawienie się sznura w heraldyce Anny Bretońskiej zostało wzmocnione powołaniem przez nią Zakonu Sznura (1'Ordre de la Cordelière), po śmierci Karola VIII w 1498 r. ${ }^{33}$ Instytucja skupiała wdowy szlacheckiego pochodzenia, w szczególności te należące do dworu królowej ${ }^{34}$. Inna wersja mówi, że zakon ufundowała królowa tuż przed swą śmiercią z myślą o tym, by wdowy szlachcianki za

${ }^{30}$ L. Hablot, Pour..., s. 55; M. Paoleti, Il Nodo: Storia, Mitologia e Misteri del simbolo più antico dell'umanità, Firenze 2015, s. 36-45.

${ }^{31} \mathrm{BnF}$, Ms. Lat. 9474, f. 1v.

${ }^{32} \mathrm{BnF}$, Ms. Français 5100, f. 2v, 13v, 15v, 17v, 25v, 40v, 42v, 49v, 51r.

${ }^{33}$ Być może wzorem dla Anny była utworzona w 1352 r. przez Ludwika III de Valois ks. d’Anjou Kawaleria Węzła (Cavaleria del Nodo). Król Neapolu powołał ja w dniu swej koronacji na cześć Ducha Świętego. Order składał się z jedwabnego węzła przetykanego złotem i perłami, noszono go na lewej piersi, na sercu. Kawalerowie orderu zobowiazani byli stawać zbrojnie przy księciu podczas wojny i służyć mu radą w czasach pokoju. Jeśli któryś $z$ kawalerów odznaczył się męstwem $\mathrm{w}$ walce $z$ nieprzyjacielem, król w trakcie specjalnej uroczystości rozwiązywał jego węzeł, co obligowało posiadacza orderu do odbycia pielgrzymki do Ziemi Świętej. Do innych powinności kawalera należał post co piątek oraz świadczenie jałmużny na rzecz ubogich. Na bazie kawalerii w 1579 r. Henryk III powołał Order Świętego Ducha. Por. F. Prato, Dizionario storico portatile degli ordini religiosi e militari e delle congregazioni regolari e secolari ch contiente la loro origine, i loro progressi, la loro decadenza, e lei differentia loro riforme, Torino 1742, s. 260.

${ }^{34}$ A. Favin, Le Théâtre d'honneur et de chevalerie, ou l'histoire des ordres militaires etc., Paris 1610, s. 903-904; H. de Sain te-Marie, Dissertations historiques et critiques sur la chevalerie ancienne et moderne, Paris 1718, s. 274-276; $\mathrm{A} b$ bé Gius ti n i a ni, Histoire des ordres militaires ou des chevaliers des milices etc., t. II, Amsterdam 1721, s. 267-269. 
pomoca adoracji relikwii $z$ sercem Anny Bretońskiej podnosiły swą moralność i pobożność oraz żyły w cnocie $^{35}$. Dewizą zakonu były słowa zaczerpnięte $z$ motta herbowego „J'ay le corps délié”, czyli „Uwalniam swe ciało”, należącego do Ludwiki de la Tour d'Auvergne, wdowy po Klaudiuszu de Montagu panu de Couches ${ }^{36}$. Wpisywało się to $\mathrm{w}$ zadania postawione stowarzyszeniu, polegajace na ascezie, kontemplacji i modlitwie, dzięki którym członkinie miały wyzbyć się grzechu, pożądliwości i przywiązania do dóbr materialnych. Ponadto wyrażenie corps délié stanowiło, w warstwie fonetycznej, naśladownictwo słowa cordelière, co uznać należy za grę słów charakterystyczna dla kultury dworskiej.

Następczyni Anny na królewskim tronie, trzecia żona Ludwika XII Maria Tudor (1496-1533), nie dołączyła sznura wdowiego do swego herbu. Przypomnijmy, że jej małżeństwo zawarte w październiku 1514 r. zakończyło się po niespełna trzech miesiącach, na skutek śmierci króla. Maria, zwana „Różą Tudorów”, poślubiła w tajemnicy przed swym bratem, królem Anglii Henrykiem VIII, Karola Brandona ks. Suffolk i opuściła Francję. Nie było zatem większych przesłanek, by Maria używała symbolu sznura w swym herbie. Kolejna władczynią, która umieściła sznur w swym herbie, była Ludwika Sabaudzka (1476-1531), wdowa po Karolu d'Orléans hr. d'Angoulême i matka przyszłego monarchy Franciszka I. Splot sznura wokół tarczy herbowej przybrał dwie formy. Pierwsza wersja ukazywała sznur łączacy tarczę herbową lub monogramy Ludwiki z herbem męża oraz ich dzieci - Franciszka i Małgorzaty d'Angoulême ${ }^{37}$. Ze szczególną formą spotykamy się w przypadku kompozycji emblematycznej z dzieła Franciszka Du Moulines de Rochefort podejmujacego watki religijne w kontekście filozofii neoplatońskiej. Autor nadał członkom rodziny królewskiej miana cnót. Ludwik XII pod znakiem Jupitera oznaczał Dobro (Le Bon), Franciszek I uosabiał piękno (Le Beau) w znaku Merkurego, natomiast Małgorzata wyobrażała Sprawiedliwość (La Justice) przynależną

${ }^{35}$ P. Hélyot, M. Bullot, Histoire des ordres monastiques, religieux et militaires etc., Paris 1719, s. 427-428. W „Commémoration de la mort d'Anne de Bretagne” znajduje się ilustracja ukazująca relikwiarz z sercem królowej okolony sznurem franciszkańskim. Ibidem, f. 51v, 55r.

${ }^{36}$ L. Hablot, Pour..., s. 48.

37 Ecus aux armes de Charles d'Orléans-Angoulême, Louise de Savoie, François et Marguerite d'Angoulême, [w:] Brunetto Latini, Le Livre du trésor, Tours 1510, BnF, Ms. Français 19088, fol. 1r.; Tapiseria herbowa Ludwiki Sabaudzkiej i Charles'a d'Orléans, Museum of Fine Arts w Bostonie, accession 36.136. 
Saturnowi. Postacie i ich personifikacje zostały związane sznurem, którego elementem wieńczącym jest Duch Święty ukazany pod postacia gołębicy i nazwany Parakletem, czyli Ożywicielem ${ }^{38}$.

Druga wersja wiązania ukazywała sznur o ośmiu węzłach, okalający tarczę herbową księżnej, co znalazło odzwierciedlenie m.in. na jej pieczęci oraz żetonach (jeton du chambre) ${ }^{39}$. Jej uzasadnienia należy się doszukiwać w tradycji sabaudzkiej przeszczepionej w XV w. na grunt francuski i w elemencie heraldycznym zwanym „węzłem miłości” lub „pułapką miłości” (lacs d'amour). W 1350 r. Amadeusz VI hrabia Sabaudii utworzył Zakon Więzów Miłości (zwany też Zakonem Czarnego Łabędzia), który około 1434 r. został przekształcony w Zakon Zwiastowania Najświętszej Marii Panny ${ }^{40}$. Symbol węzła zwanego noeud de Savoie przetrwał zresztą do dziś w insygniach orderowych. Zmianie uległo jedynie tłumaczenie symbolu. W XII i XIV w. sznur i węzeł wyobrażały miłość ziemska, przepełnioną dwornością i cnota, podczas gdy w wieku XVII starano się dokonać ich teologicznej egzegezy i związać z miłością boską łącząca człowieka ze Stwórca w tajemnicy wcielenia ${ }^{41}$.

Poza tym na posługiwanie się przez Ludwikę symbolem sznura wpływała określona gra słowna. Cordelière, czyli sznur, oraz łacińskie słowo Concordia, czyli zgoda, miały swoje źródło w słowie cor, -dis, oznaczajacym serce. Zwracano zatem uwage na pojednawczy i pokojowy charakter władzy Franciszka, który po wymarciu gałęzi Walezjuszy orleańskich przejął rządy nad Francją w 1515 r. Przyjmujac takie tłumaczenie, Ludwika akcentowała dodatkowo kult serca Anny Bretońskiej, wokół którego funkcjonował Zakon Sznura ${ }^{42}$. Wymowa ta wzmocniła się wraz $z$ poślubieniem przez

38 BnF, Ms. Français 1993, f. 2v; K. Wils on-Chevalier, "Trinités royales" et "quadrangle d'amour": Claude de France. Marguerite de Navarre, François I'r Louise de Savoie et le réforme fabriste de l'Église, [w:] "La dame de coeur". Patronage et mécénat religieux des femmes de pouvoir dans l'Europe des XIVe-XVII siècles, sous le direction de M. Gaude-Ferragu, C. Vincent-Cassy, Rennes 2006, s. 123-136.

${ }^{39}$ AnF Centre, D-170; BnF, Cabinet des médailles, 4480.

${ }^{40}$ F.-J.-M. N oё1, Nouveau dictionnaire des origines, inventions et découvertes, t. I, Paris 1827, s. 61-62.

${ }^{41}$ C.O. Fine de Briaville, Jeu d'Armoires des souverains et estates d'Europe, Lyon 1665, s. Ss (za zwrócenie mi uwagi na istnienie Zakonu, symbolikę sznura sabaudzkiego oraz cytowana pracę pragnę złożyć serdeczne podziękowania dr. hab. Igorowi Kraszewskiemu z Uniwersytetu im. Adama Mickiewicza w Poznaniu).

${ }^{42} \mathrm{C} . \mathrm{M} \mathrm{az}$ el, À corps et à cours: les monuments funéraires des Valois, 1461-1589, [w:] Les Funérailles princières en Europe XVI $-X V I I I^{e}$ siècle, t. II (Apothéoses mo- 
Franciszka I córki Anny Bretońskiej i Ludwika XII, Klaudii Francuskiej (1499-1524). Królowa, poza tytulatura przypominająca jej zwierzchność nad Bretanią, posługiwała się w swym godle, obok złotych lilii, także gronostajem $z$ herbu księstwa. Tarcza herbowa opleciona była sznurem, choć Klaudia nie była wdowa ${ }^{43}$. Sznur do swego herbu wdowiego przyjęła natomiast druga żona Walezjusza, Eleonora Habsburżanka, zwana też Kastylijska (1498-1558) ${ }^{44}$. Dodajmy, że Franciszek I, już na początku swych rządów, dokonał mało widocznego, lecz ważnego zabiegu w kompozycji własnego herbu. Polegal on na zastąpieniu sznurem ogniw spinajaccych muszle w łańcuchu orderu św. Michała ${ }^{45}$. Innym razem sznur oplatał ukoronowany monogram królewski lub któryś $z$ emblematów Franciszka I - salamandrę lub złotą lilię ${ }^{46}$. W ten sposób monarcha francuski wskazał na siebie jako dziedzica pamięci, ziem i tytułów Anny Bretońskiej i jej córki Klaudii, manifestując ciąłość sukcesji dynastii ${ }^{47}$.

numentales), sous les direction de J.A. Chrościcki, M. Hengerer, G. Sabatier, Versailles 2013, s. 237-241.

${ }^{43}$ [Maître des Entrées parisiennes des reines], Entrée de la reine Claude de France à Paris, Paris 1517. Szerzej: A.M. Le c o q, op. cit., s. 396-398; C.J. B row n, Claude de France: In her Mother's Likeness a Queen with Symbolic Clout?, [w:] The Cultural and Political Legacy of Anne de Bretagne. Negotiating Convention in Books and Documents, publ. D.S. Brewer, Cambridge 2010, s. 123-144; P. Tourault, Les ducs..., s. 369-378; M. Nas siet, Les reines héritères: d'Anne de Bretagne à Marie Stuart, [w:] Femmes et pouvoir politique. Les princesses d'Europe $X V^{e}-X V I I I^{e}$ siècle, sous le direction d'Isabelle Poutrin, M.-K. Schaub, Bréal 2007, s. 134-146. Sznur znalazł się też w herbie siostry Klaudii de Valois Renaty d'Este (1510-1575) i jej siostrzenicy, Anny de Guise ks. de Nemours (1531-1607).

${ }^{44}$ AnF Centre, D-173.

45 F.A. Aubert de La Chesnaye-Desbois, Dictionnaire historique des mours, usages, et coutumes des François, t. I, Paris 1768, s. 584-585; A. Surgers, Les images du règne. Le roi nous regarde, [w:] François ${ }^{2 r}$ pouvoir et image, sous le direction de B. Petey-Girard et M. Vène, Paris 2015, s. 67-77. Podobne zakomponowanie łańcucha orderowego widać na frontyspisie ukazującym herb Claude'a de Lorraine ks. d'Aumale z około 1557 r. Vide: Getty Museum, Ms. Ludwig XIII 4, f. 1 r.

46 Warto zwrócić uwage na sztukaterie zawierające motyw cyfry królewskiej z zamków w Blois i Chambord oraz na projekt tapiserii emblematycznej. Vide: Dessin d'une tapisserie à l'emblématique de François ${ }^{\mathrm{er}}$, BnF, Dép. éstampes, AD-110 (1)-FOL.

47 Po śmierci Klaudii w 1524 r., na mocy jej testamentu, prawa do Bretanii zostały przekazane delfinowi Franciszkowi, który używał tytułu księcia Bretanii do swej śmierci w 1532 r. Potem władza nad Bretania powróciła do króla Francji Franciszka I, a po jego śmierci w 1547 r. została przekazana młodszemu synowi Franciszka i Klaudii, Henrykowi II. 
Powracając jednak do sznura jako symbolu wdowieństwa, należy zauważyć, że motyw ten występował w herbie Katarzyny Medycejskiej (1519-1589), wdowy po Henryku II. Sznur oplatający tarczę herbowa królowej został umieszczony na jej pieczęci ${ }^{48}$, w ekslibri$\mathrm{sie}^{49}$ oraz na karcie tytułowej atlasu morskiego ${ }^{50}$. Jak stwierdzili Isabelle de Conihout i Pascal Ract-Madoux, eksponowanie sznura w heraldyce Medyceuszki łączyło się nie tylko z podkreśleniem jej wdowieństwa, lecz także jej praw do Bretanii, jako wiana przyznanego jej przez Henryka II $^{51}$. Ponadto Katarzyna podkreślała w ten sposób swoje silne związki z dynastią Walezjuszy, po swej matce - Madeleine de la Tour d'Auvergne (1498-1519) ${ }^{52}$.

Warto zauważyć, że po śmierci kolejnego króla Francji - Franciszka II w 1560 r. wdowa po nim, późniejsza królowa Szkocji Maria Stuart (1542-1587), nie przyjęła do swego herbu sznura. Pieczęcie królowej $z$ okresu pierwszego wdowieństwa nie zawieraja tego elementu ${ }^{53}$. Zwróćmy uwage, że jej matka, Maria de Guise (1515-1560), zarówno po śmierci pierwszego męża Ludwika II ks. de Longueville, jak i drugiego Jakuba V, króla Szkocji, posługiwała się w swym herbie motywem sznura ${ }^{54}$. Wytłumaczeniem działania Marii Stuart był zapewne jej szybki powrót do rodzinnej Szkocji, konieczność ustabilizowania tam bardzo napiętej sytuacji wewnętrznej po śmierci jej matki oraz walka o tron angielski, do którego Maria odmawiała prawa swej kuzynce Elżbiecie I Tudor. Co prawda, na mocy traktatu edynburskiego podpisanego 5 lipca 1560 r. strona francuska zobowiązywała się wycofać swe siły ze Szkocji i uznała władzę Elżbiety I, lecz Maria nie ratyfikowała

48 AnF Centre, D-171, D-171 $1^{\text {bis }}, \mathrm{D}-175$.

49 Exlibris en cartouche: „Catherine de Médicis, par la grâce de Dieu, royne de France”, Bibliothèque Municipale w Aix-en-Provence, Ms. 0638, f. 4r.

50 Atlas nautique portugais dit „Atlas Miller”, BnF, département Cartes et planes, GE D 26179 (RES), f. 1v.

${ }^{51}$ I. de Conihout, P. Ract-Madoux, Veuves, pénitents et tombeaux. Reliures françaises funèbres, Catherine de Médicis et Henri III, [w:] Les funérailles à la renaissance: XIIe colloque international de la Société française d'étude du seizième, sous le direction de J. Balsamo, Genève 2002, s. 230-232.

52 A. Vilain-De Bruy ne, Le cachet de Catherine de Médicis. Une matrice réginale inédite, „Revue de la Bibliothèque nationale de France” 2013, no. 43, s. 74-78.

53 AnF Centre, D-10260, D-10261, D-10262.

${ }^{54}$ Wskazać można m.in. na dekorację heraldyczną w zamku Leith koło Edynburga i w Stirling w Szkocji. Vide: E. Viennot, Veuves de mère en fille au XVI siècle: le cas du clan Guise, [w:] Veufs, Veuves et veuvage dans la France d'Ancien-Régime, sous le direction N. Pellegrin, C. Winn, Paris 2003, s. 187-198. 
traktatu. Opisane okoliczności narzuciły niejako program i kompozycje jej herbu. Eksponowanie w nim francuskich akcentów, takich chociażby jak sznur, mogło okazać się niezrozumiałe, nieaktualne, a co najważniejsze - niewłaściwe.

Tradycja dodawania sznura do herbów wdowich królowych Francji bynajmniej nie zanikła. Do swego herbu włączyła go Elżbieta Austriacka (1554-1592)55, po śmierci Karola IX w 1574 r., oraz Ludwika Lotaryńska (1553-1601) ${ }^{56}$, po śmierci Henryka III w 1589 r. Tak samo uczyniła Maria Medycejska, po śmierci Henryka IV w 1610 r., wraz $z$ objęciem regencji w imieniu małoletniego Ludwika XIII. Zachowały się aż cztery wzory pieczęci królowej $z$ tego okresu, w tym jeden $z$ pieczęci mniejszej i jeden $z$ pieczęci sygnetowej ${ }^{57}$. Wizerunek herbu Marii Medycejskiej otoczonego sznurem odnaleźć można w detalu ryciny ukazującej młodego Ludwika XIII na koniu ${ }^{58}$ oraz na frontyspisie tzw. modlitewnika mniejszego należącego niegdyś do Anny Bretońskiej59. Powód, dla którego królowa próbowała odwołać się do swej poprzedniczki na królewskim tronie, jest na razie nieznany. Być może zależało jej na legalizacji władztwa Burbonów oraz na podkreśleniu ciagłości panowania, tak jak uczyniła to poprzednia dynastia względem Walezjuszy orleańskich. Sądzić można, że królowa próbowała zamanifestować w ten sposób potrzebę jedności Francji, przeciwstawiając się separatyzmowi księstwa Bretanii. Innym wytłumaczeniem mogłoby być nawiązanie do dalekiej krewnej Marii, Katarzyny Medycejskiej, która $z$ podobnej pozycji wdowy wywierała przemożny wpływ na sprawy polityczne kraju. Przypuszczać można, że

55 AnF Centre, D-176.

56 Nie zachowały się wizerunki napieczętne herbu Ludwiki z okresu jej wdowieństwa. Warto jednak za przykład posługiwania się przez królową wdowę motywem sznura podać kompozycję heraldyczna umieszczona w kasetonach zdobiących strop w komnacie Pięciu Królowych w zamku w Chenonceau. Królowa spędziła na zamku okres żałoby po śmierci męża i pozostawała w nim aż do swej śmierci w $1601 \mathrm{r}$.

57 AnF Centre, D-177, D-178, D-179, D-180. O zamówieniach nowych matryc do pieczęci przez królowa i jej dyspozycjach por. Quand Marie de Médicis commande ses sceaux [serwis BnF - Sceaux et actes scellés de la Bibliothèque nationale de France], http://sceau.hypotheses.org/627 (dostęp: 17 III 2017).

58 Portrait de Louis XIII, à cheval, coiffé d'un chapeau rond; dans le haut aux deux côtés de la planche les portraits de Henri IV et de Marie de Médicis, BnF, département Estampes et photographie, QB-201 (36)-FOL.

59 Armes de Marie de Médicis, reine de France, avec la cordelière de veuve, "Petites Heures de la reine Anne de Bretagne", 1401-1500, BnF, Ms NAL 3027. 


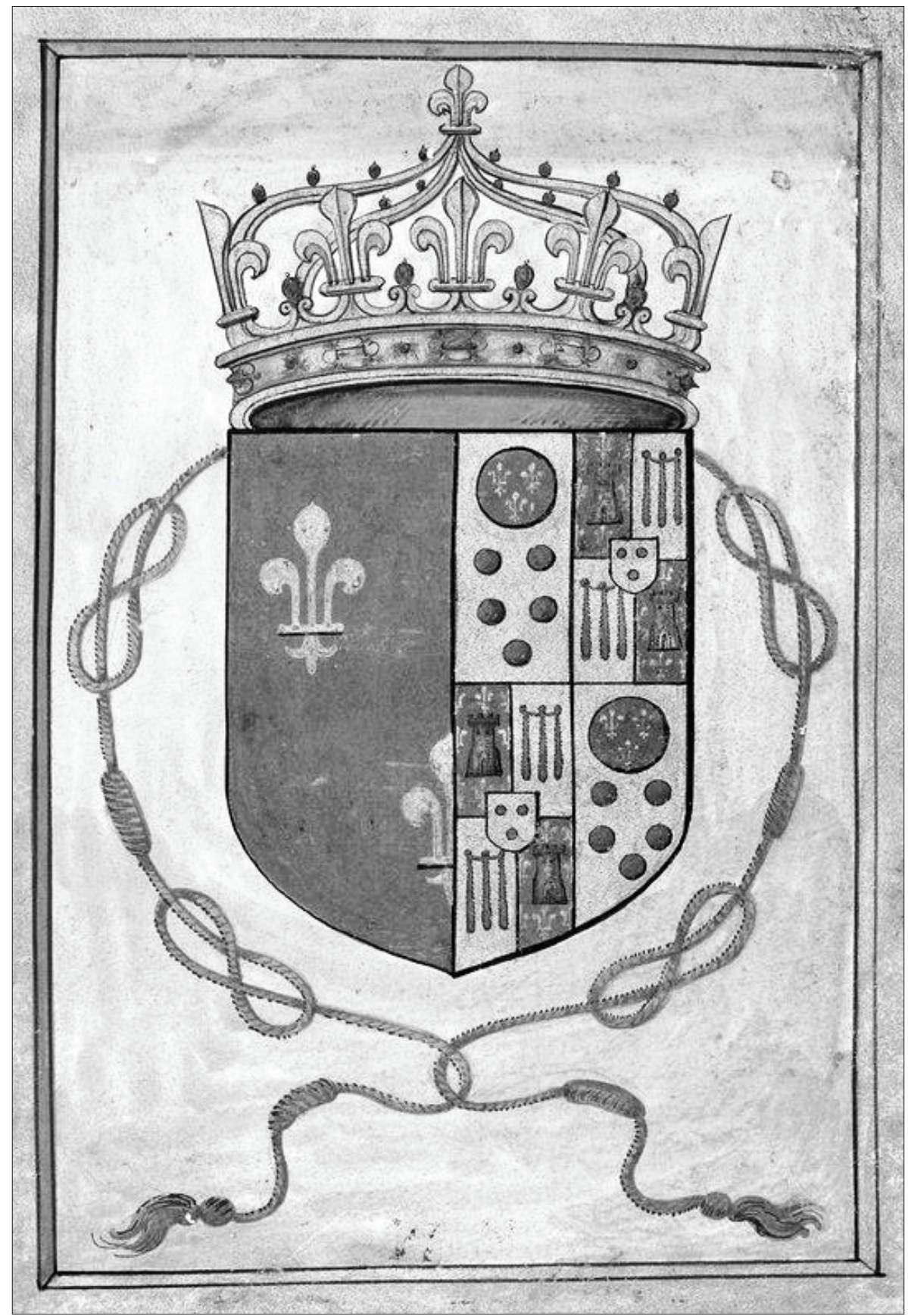

3. Herb Marii Medycejskiej ze sznurem wdowim, Bibliothèque nationale de France w Paryżu Ms NAL 3027 „Petites Heures de la reine Anne de Bretagne”, 1401-1500, f. Br 
Maria, jako regentka, starała się przyrównać do wdowy po Henryku II oraz zaakcentować swoje zwierzchnie rządy.

Ostatnią królową, która włączyła sznur do swojego herbu, była Anna Austriaczka $(1601-1661)^{60}$. Widać to na przykładzie pieczęci królowej ${ }^{61}$, licznych kompozycji heraldycznych w postaci projektów graficznych ${ }^{62} \mathrm{w}$ grafice portretowej ${ }^{63}$, na obwolutach ksiag $z$ jej biblioteki ${ }^{64}$ oraz $\mathrm{w}$ zainteresowaniach królowej funkcjonowaniem wspólnoty franciszkańskiej w ramach trzeciego zakonu (tercjarzy) i jej wsparcia dla działalności Archikonfraterni Sznura św. Franciszka powołanej w 1587 r. przez papieża Sykstusa V65.

Tak jak jej teściowa, Anna w chwili śmierci męża Ludwika XIII w 1643 r. objęła - choć wbrew woli zmarłego - regencję i powołała na urząd pierwszego ministra, kardynała Juliusza Mazarina. Anna poza wyraźnym zaangażowaniem w politykę, w tym w walkę $z$ fakcjami dworskimi, wyróżniała się szczególną pobożnością, wynikająca $z$ jej wychowania na dworze hiszpańskim, przepełnionym gorliwością religijną oraz $z$ późniejszego sprzyjania odbudowie potęgi Kościoła we Francji, z jednoczesnym potępieniem różnowierców oraz sympatyków nowinek religijnych, m.in. jansenistów ${ }^{66}$. Anna patronowała nie tylko zakonom „nowego typu”, np. jezuitom, szarytkom i lazarystom, lecz także otaczała swa opieka stare zakony kontemplacyjne, w tym benedyktynów-cystersów oraz ich żeńska gałąz. Tym ostatnim ufundowała w 1621 r. klasztor pod Paryżem Val-de-Grâce de la vallée de la Bièvre ${ }^{67}$. Po narodzinach delfina,

${ }^{60}$ Zwróćmy uwagę, że do czasów Wielkiej Rewolucji władcy, tj. Ludwik XIV, Ludwik XV i Ludwik XVI, żyli dłużej niż ich żony, a zatem nie było już królowych wdów. Nie istniały zatem podstawy do umieszczania w ich herbie sznura.

${ }^{61}$ AnF Centre, D-181, D-183.

${ }^{62}$ Coat of arms of Queen Anne of Austria, surmounted by crown, surrounded by six Spirits, aut. G. Hurtet, ok. 1643, British Museum, Department of Prints and Drawnings, 1858,0417.1436.

${ }^{63} \mathrm{AnF}$, Collections iconographiques AE/II/3216; B. G a e th ge n s, Les portraits d'Anne d'Autriche. L'image royale au service de la politique, [w:] Anne d'Autriche. Infante d'Espagne et reine de France, dirigé Ch. Grell, Paris 2009, s. 209-243.

${ }^{64}$ L'office de la Semaine saincte, Paris 1627, Princton University Library, 5942.244 .12 .

${ }^{65}$ Livret de l'archiconfrérie du Cordon de Saint-François: origine, obligations, indulgences, cérémonial, diplôme, ed. Société et libr. Saint-François, Paris 1929, s. 6-8.

${ }_{66}$ M. J. del Rì Barredo, Enfance et éducation d'Anne d'Autriche à la cour de Espagne (1601-1615), [w:] Anne d'Autriche..., s. 111-155; J. Bergin, Anne d'Autriche et les dévots, [w:] ibidem, s. 187-190.

${ }^{67}$ F. de Motteville, Anna Austriaczka i jej dwór, Warszawa 1978, s. 122-142, 163-164; A. Gady, Anne d'Autriche et Paris, [w:] Anne d'Autriche..., s. 305-311. 
przyszłego króla Ludwika XIV, w 1638 r. Anna chcąc wyrazić swe dziękczynienie, przeznaczyła dodatkowe fundusze na rozbudowę świątyni. Dzięki licznym uposażeniom powstał ogromny kompleks klasztorno-szpitalno-pałacowy, do którego królowa przybywała wraz $z$ dworem, pragnacc oddać się modlitwie i kontemplacji, szczególnie w okresie poprzedzającym Boże Narodzenie oraz w Wielki Tydzień. Anna odbywała nadto liczne pielgrzymki do sanktuariów w Les Ardilliers, Liesse i Chartres oraz przeznaczała pieniądze na dzieła miłosierdzia, w tym szpitale i przytułki ${ }^{68}$. Wobec powyższego uznać można, że eksponowanie sznura w heraldyce Anny Austriaczki nie było tylko wyrazem tradycji i określonych ambicji politycznych, lecz także podkreśleniem jej głębokiej dewocji.

Liczne przykłady pochodzace $z$ heraldyki francuskiej pokazuja, że sznur został włączony do herbów wdów $z$ kręgów dworskich. Taka praktyka wydaje się w pełni usprawiedliwiona, $z$ punktu widzenia powołania przez Annę Bretońska w końcu XV w. Zakonu Sznura skupiającego właśnie wdowy $z$ rodzin królewskiej i arystokratycznych, zatem elity społecznej ${ }^{69}$. $Z$ czasem motyw ten utrwalił się w heraldyce kobiet $z$ rodziny królewskiej. Wspomnijmy zatem kompozycje heraldyczne umieszczone w grafice portretowej Krystyny de Bourbon (1606-1663), naturalnej córki Henryka IV i przyrodniej siostry Ludwika XIII, a wdowy po Wiktorze Amadeuszu I Sabaudz$\mathrm{kim}^{70}$, następnie przy podobiźnie Katarzyny Henrietty de Bourbon-Vendôme (1596-1663), wdowy po Karolu II ks. d'Elbeuff', a także w wizerunkach prawnuczki Henryka IV i wdowy po księciu Karolu Emanuelu II, Marii Joanny de Savoie-Nemours (1644-1724) 72 i Katarzyny Henreitty de Joyeuse ks. de Guise (1585-1656), wdowy po Karolu I ks. de Lorraine ${ }^{73}$. Element ten występuje również na obwolutach książek z biblioteki Anny Bawarskiej (1648-1723),

68 J. Bergin, op. cit., s. 190-209; W.S. Magdziarz, Anna Austriacka, Warszawa 2013, s. 140-141.

${ }^{69}$ L. Hablot, Pour..., s. 58-59.

70 Portrait of Cristina of Bourbon-France (1606-1663), Duchess of Savoy aut. Balthasar Moncornet, ok. 1658, Getty Museum w Los Angeles, 700719269.

${ }^{71}$ https://en.wikipedia.org/wiki/Catherine_Henriette_de_Bourbon\#/media/File: Catherine_Henriette_de_Bourbon,_Légitimée_de_France,_1659.jpg (dostęp: 19 III 2017).

72 Portrait de Marie Jeanne Baptiste de Savoie, aut. R. Nanteuil, ok. 1678, Princeton University Library. Graphic Arts. GA 2005.00584.

$73 \mathrm{AnF}$, Collections iconographiques, AE/II/3191. Warto zwrócić uwage na herb Henrietty umieszczony w portalu l'Hôtel de Clisson (obecnie l'Hôtel de Soubise) przy rue de Archives w Paryżu. 
córki Edwarda Wittelsbacha i Anny Gonzagi, wdowy po Henryku Juliuszu ks. de Bourbon-Condé ${ }^{74}$, oraz na egzemplarzach należących do naturalnych córek Ludwika XIV i Franciszki de Montespan: Ludwiki Franciszki de Bourbon $(1673-1743)^{75}$, wdowy po Ludwiku III ks. de Bourbon-Condé, i do Franciszki Marii de Bourbon (1677-1748) ${ }^{76}$, wdowy po Filipie ks. Orleanu.

Sznur otaczał też tarcze herbowe dam ze sfery arystokratycznej. Jako przykłady wskazać można herb Małgorzaty de Forbin-Janson, wdowy po Karolu d'Arcussia panu d'Esparon zmarłym po 1619 r., ukazany obok jego właścicielki na obrazie adoracji Matki Bożej Różańcowej w kościele Notre-Dame de l’Assomption w Esparon de Pallières z 1628 r., w herbie siostrzenicy kardynała Richelieu, Marii Magdaleny de Vignerot pani de Combalet i diuszesy d'Aiguillon (1604-1675) w witrażu okna Hôtel-Dieu w Québecu z 1693 r. ${ }^{77}$, na plakiecie kominkowej $z$ herbem Anny Croix, wdowy po Janie III d'Ambournay zmarłym w $1691 \mathrm{r}^{78}$, na obwolucie ksiażki z biblioteki Anny Małgorzaty de Beauvau-Craon (1707-1791), wdowy po Gastonie de Levis, diuku de Mirepoix ${ }^{79}$, oraz na litre (szerokim pasie dekoracyjnym, na którym umieszczano inicjały lub herby zmarłego) $z$ herbem pani de Mulot, wdowy po sekretarzu królewskim i skarbniku Henryku Józefie Vachier panu de Nonancourt w kościele w Andé ${ }^{80}$ (Normandia, departament Eure). Przykłady te można mnożyć. Wynika $z$ tego, że dołączanie sznura do tarcz herbowych wdów w wiekach XVI, XVII i XVIII było bardzo popularne. Element ten nie funkcjonował jako wyłącznie przynależny królowym i damom $z$ rodziny królewskiej.

Na koniec dodajmy, że eksponowanie sznura w heraldyce bywało przedmiotem świadomej kreacji. $Z$ takim przykładem spotykamy

${ }^{74}$ http://www.bibliotheque-conde.fr/expositions/histoire-de-la-reliure/reliuresaux-armes-des-seigneurs-de-chantilly-xvie-xixe-siecle/ (dostęp: 19 III 2017).

75 http://ombresdemeslivres.wifeo.com/louise-francoise-de-bourbon.php (dostęp: 19 III 2017).

76 http://ombresdemeslivres.wifeo.com/mlle-de-blois-duchesse-d-orleans.php (dostęp: 19 III 2017).

77 http:/ / passion-heraldique.blogspot.com/2012/12/armorial-du-parlement-de-quebec-6e.html (dostęp: 19 III 2017).

78 http:/ / www.anticstore.com/plaque-cheminee-decoree-un-blason-cordeliere-22823P (dostęp: 19 III 2017).

${ }^{79}$ http:/ / bibliophilie.blogspot.com/2012/11/miscellanees-dubibliophile-bredouille.html (dostęp: 19 III 2017).

${ }^{80} \mathrm{http}$ :/ / www.ande.fr / DetailElement.aspx?numStructure=78849\&numElement=76997 (dostęp: 19 III 2017). 
się w przypadku herbów $z$ witraży kaplicy w Champigny-sur-Vuede (Centre-Val de Loire, departament Indre-et-Loire). Świątynia ta została ufundowana pod koniec XV w. przez Ludwika ks. de Bourbon-Vendôme, wnuka Ludwika IX Świętego, na wzór paryskiej Saint-Chapelle, w której kultem otaczano relikwie Męki Pańskiej. W latach 1538-1561 kaplica doczekała się pełnej restauracji $z$ inicjatywy Ludwika III ks. de Bourbon-Montpensier, zgłaszajaccego swe prawa do korony francuskiej na wypadek wymarcia dynastii Walezjuszy. W wystroju kaplicy, w szczególności w programie scen witrażowych, umieszczono postacie przodków odnowiciela przybytku i towarzyszące im herby. Władców i ich żony przedstawiono w pozycji klęczącej, skierowanych w stronę ołtarza głównego. Warto zauważyć, że królowym Małgorzacie z Prowansji (1221-1295) i Beatrycze de Bourbon (1257-1310) oraz damom Marii d'Avesnes d'Hainaut (1280-1354), Izabeli de Châtillon Saint-Pol (ok. 1285-1354), Marii de Berry (1370-1434), Gabrieli de la Tour (ok. 1422-1486), Klarze Gonzadze (1441-1484), Zuzannie de Bourbon (1491-1521) i Ludwice de Bourbon-Montpensier (1482-1561) przypisano herby otoczone sznurem. Przykład ten dowodzi, poza popularnością motywu i jego wpisaniem w symbolikę pasyjna, jego przynależności do dziedziny związanej z symboliką władzy ${ }^{81}$. Ludwik III dawał w czytelny sposób do zrozumienia, że łącza go więzi nie tylko ze świętym królem Ludwikiem, lecz także Ludwikiem XI (dziadkiem macierzystym Zuzanny de Bourbon), Karolem VIII (wujem Zuzanny de Bourbon), Franciszkiem I (prawnukiem Karola I de Bourbon i bratem przyrodnim żony Louisa III ks. Bourbon-Montpensier) oraz $z$ dynastia Montfort $z$ Bretanii, ponieważ druga żoną Ludwika III ks. Burobon-Montpensier była Katarzyna Lotaryńska, córka Franciszka de Guise i Anny d'Este, po kądzieli prawnuczka Anny Bretońskiej.

$$
* * *
$$

${ }^{81} \mathrm{Na}$ ten temat szeroko por. L.A. Boss eboeuf, Château et la Sainte-Chapelle de Champigny-sur-Veude (Indre-et-Loire), notice historique et archéologique, Tours 1881, s. 19-35; L. Grodecki, M. Callias Bey, F. Perrot, Les Vitraux du Centre et des Pays de la Loire, [w:] Corpus vitrearum, Éditions du Centre National de la Recherche Scientifique, Paris 1981, s. 103-108; L. Riviale, Les verrières de la Sainte-Chapelle de Champigny-sur-Veude (Indre-et-Loire), [w:] Congrès archéologique de France. $155^{e}$ session. Monuments en Touraine, ed. Société Française d'archéologie, Paris 2003, s. 55-76. 
Dochodzimy do momentu, w którym należy zastanowić się nad powodami włączenia sznura przez królową wdowę Marię Kazimirę d'Arquien Sobieska do jej herbu. Powtórzmy za Laurentem Hablotem zestaw pytań, jakie badacz postawił, rozważając przyczyny posługiwania się tym elementem przez szlachtę bretońską ${ }^{82}$. Czy była to kwestia mody? Czy był to wyraz pobożności jednostki, praktykowanej w duchu franciszkańskim? Czy też przyjęcie sznura łączyło się $z$ ambicjami i próbą awansu społecznego?

W przypadku pierwszego pytania odpowiedź jest przeczaca. Moda, zgodnie $z$ definicja, jest zjawiskiem nietrwałym, zmiennym, chwilowym i łączącym się z zapotrzebowaniem społecznym na coś w danej chwili. Modzie ulegamy w sposób nieświadomy. Powyższa analiza, ukazująca wytrwałe użytkowanie sznura w heraldyce wpierw bretońskiej, a potem francuskiej na przestrzeni od XVI do XVIII w., zdecydowanie nie daje się pogodzić z pojęciem mody. Możemy, co najwyżej, mówić o upowszechnieniu się symbolu w heraldyce wdów ze sfer arystokratycznych. Zapewne też Maria Kazimiera nie kierowała się modą, ponieważ włączenie przez nią do swego herbu sznura było działaniem świadomym.

Na drugie pytanie odnoszace się do przesłanek dewocyjnych można odpowiedzieć twierdząco. Religijność Marii Kazimiery d'Arquien Sobieskiej stanowi - jak dotąd - dziedzinę słabo zbadaną ${ }^{83}$, niemniej wiele wskazuje na to, że królowa należała do osób pobożnych ${ }^{84}$. Dla naszych rozważań istotne jest przypomnienie fundacji kościoła i klasztoru zakonu benedyktynek od nieustającej adoracji Najświętszego Sakramentu, zwanych popularnie sakramentkami, w Warszawie w latach 1688-1692 i ich uposażanie przez królową do czasu jej śmierci. Charyzmat zakonu, któremu ostateczną formę nadała matka Mechtylda du Bar w Lotaryngii,

${ }^{82}$ L. Hablot, Pour..., s. 58.

${ }^{83}$ Pewne wzmianki na ten temat por. M. Ko mas zyńs ki, Maria Kazimiera Sobieska d'Arquien Sobieska, królowa Polski (1641-1716), Kraków 1983, s. 153-156; id e m, Piękna królowa Maria Kazimiera d'Arquien-Sobieska, 1641-1716, Warszawa 1995, s. 197-200; D. Ro s ińs ka, Jana Sobieskiego życie religijne, [w:] Z dziejów XVII i XVIII wieku. Ksiega jubileuszowa ofiarowana Profesorowi Michałowi Komaszyńskiemu, red. J. Kwak, Katowice 1997, s. 65-84.

${ }_{84}$ Jan Stanisław Jabłonowski pisał, że: „Ta nieoszacowana Maria Kazimiera królowa, bywszy cudem urody i rozumu stała się cudem nabożeństwa w Rzymie, gdzie na podziwienie świata do Francji się przeniósłszy ta święta pani umarła w mieście Blois". Por. J.S. Jabło nowski, Traktat o familiach $i$ koligacjach, wyd. M. Górny, Wrocław 2015, s. 430. 
stał się popularny w drugiej połowie XVII w. i koncentrował się na przebłaganiu Boga za grzechy ludzkości poprzez nieustająca modlitewną adorację Najświętszego Sakramentu i kontemplację życia Chrystusa ${ }^{85}$. Podobna fundacja powstała zresztą daleko później w rzymskiej rezydencji królowej w Palazzo Zuccari ${ }^{86}$. Wspomnieć należy, że pobyt królowej w Rzymie w latach 1699-1714 owocował w wiele okazji do demonstracji jej pobożności, z kulminacją w czasie wielkich świąt liturgicznych, m.in. Bożego Narodzenia, Wielkiego Tygodnia czy Bożego Ciała ${ }^{87}$. Znane są nam także pobyty królowej w klasztorze benedyktynek Santa Maria in Campo Marzio w latach 1704-171488, a w czasach jej rezydencji w Blois - u miejscowych benedyktynek urszulanek ${ }^{89}$.

Królowa darzyła ogromnym kultem postać świętego Franciszka ${ }^{90}$. Utrzymywała także kontakt $z$ jedna $z$ gałęzi zakonu franciszkańskiego - kapucynami, których klasztor ufundowała w Warszawie wraz ze swym małżonkiem w 1681 r. ${ }^{91}$ Przypomnijmy, że kapucyni oddali rodzinie królewskiej rozliczne przysługi, m.in. sprawując pieczę nad ciałem króla po jego śmierci oraz nad ruchomościami po nim ${ }^{92}$. Królowej zarówno w Rzymie, jak i w Blois towarzyszył kapucyn, ojciec Ludwika d'Amsterdam sprawujący opiekę dusz-

${ }^{85}$ I.M. Walicka, Kościół i klasztor Sakramentek w Warszawie. Pomnik Zwycięstwa pod Wiedniem, Warszawa 1988.

86 Narodowe Archiwum Historyczne Białorusi w Mińsku, Archiwum Sobieskich z Oławy, f. 695, op. 1, nr 344.

87 G.M. Cres ce mbe ni, Notizie Istoriche degli Arcadi morti, t. III, Roma 1721, s. 1-9; M. Ko mas zyń s ki, Maria Kazimiera..., s. 220-222.

88 Archivio di Stato di Roma, Fondo Congregazioni Religiosi Benedettine in S. Maria in Campo Marzio, regola 62, k. 238, 250-251; regola 63, k. 231, 336; regola 64, k. 237, 240, 241; regola 65, k. 266-270; regola 66, k. 248, 266.

89 M. Ko maszyńs ki, Maria Kazimiera..., s. 270.

90 M.K. d'Arquien Sobieska do Maksymiliana Emanuela Wittelsbacha, Rome $1 \mathrm{X}$ 1714, [w:] Lettres inédites: Louis XIV, Philippe V, roi d'Espagne, Guillaume III, roi d'Angleterre, Marie-Louise de Savoie, reine d'Espagne, Marie Casimire, reine de Pologne (1680-1714), avec introduction et notes par M. Jametel, Paris 1898, s. $148-150$.

${ }^{91}$ M.K. d'Arquien Sobieska do Francesco d'Arezzio, Warszawa [?.?] 1692, Biblioteka Uniwersytetu Warszawskiego [dalej: BUW], sygn. 30, s. 7v-8v; M.K. d'Arquien Sobieska do Carlo Barberiniego, Javorova 17 XII 1681, [w:] Polonia e Curia Romana. Corrispondenza di Maria Kazimiera Sobieska regina di Polonia, con Carlo Barberini prottetore del regno (1681-1699) e il soggiorno romano di una famiglia polacca in esilio, a cura di G. Platania, Viterbo 2016, s. 184.

92 A. Skrzypietz, Królewscy synowie - Jakub, Aleksander i Konstanty Sobiescy, Katowice 2011, s. 256-260; e ade m, Infant Jan, czyli ostatni królewski 


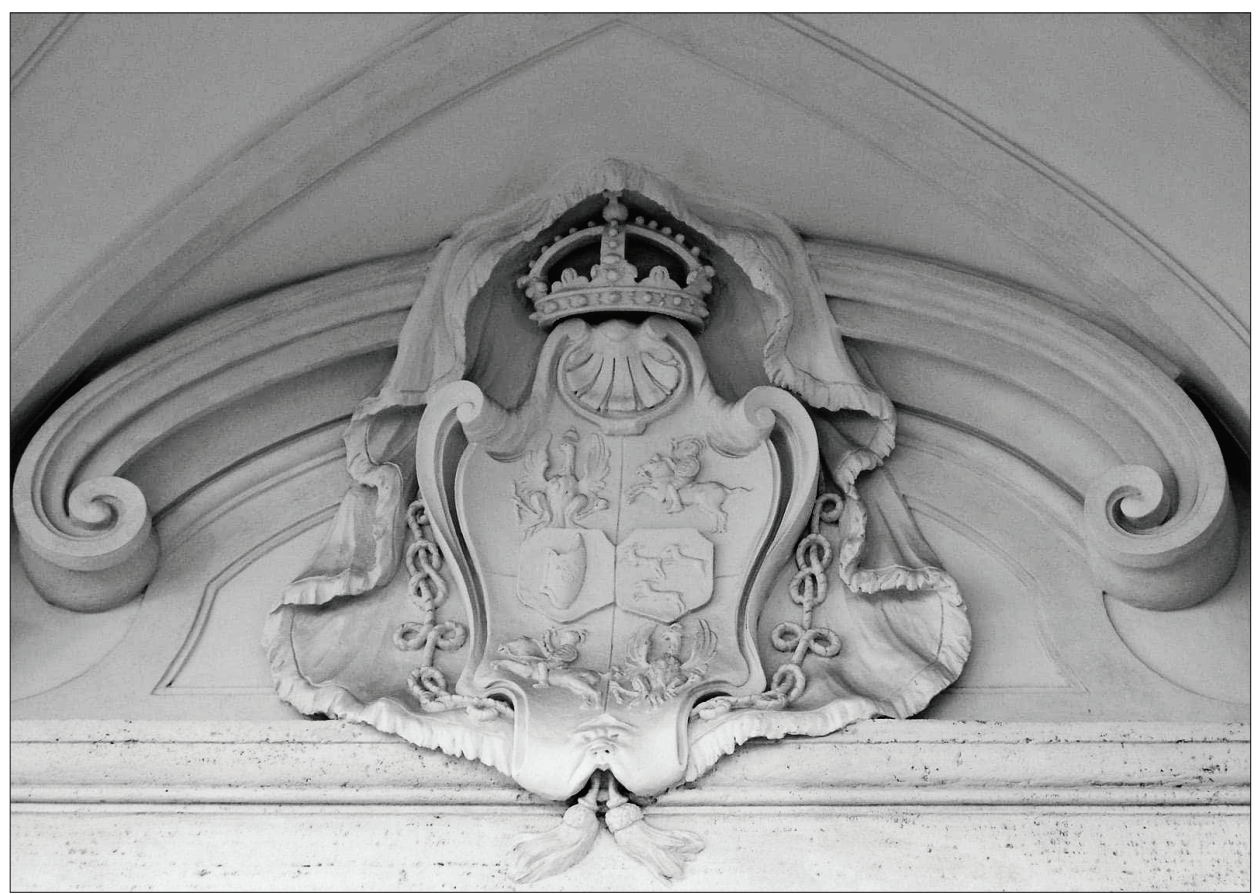

4. Herb Marii Kazimiery d'Arquien Sobieskiej na fasadzie Palazzo Zuccari w Rzymie, proj. F. Juvarra, 1704-1714 r. (fotografia w zbiorach Autora)

pasterską ${ }^{93}$. Maria Kazimiera utrzymywała też bliskie stosunki $z$ ich placówką w Rzymie ${ }^{94}$. Rozważajac symbolikę sznura w herbie monarchini w kategoriach religijnych, warto zwrócić uwagę na zadedykowany jej wiersz autorstwa Jana Bartłomieja Casaregi (pseudonim Eritro Faresio), należącego do tej samej, co królowa

pogrzeb na Wawelu, [w:] W podróży przez wiek osiemnasty. Studia i szkice z epoki nowożytnej, red. A. Perłakowski, M. Wyszomirska, M. Zwierzykowski, Kraków 2015, s. 74-75.

93 Annali manoscritti della Provincia Roma dei Frati Cappuccini (1674), vol. III, pag. 337-338-339, Archivio Provinciale dei Frati Minori Cappuccini - Roma (podziękowania za udostępnienie materiału składam Pani Zuzannie Flisowskiej z Muzeum Pałacu Króla Jana III w Wilanowie); P. Hild e brand, Le père Louis d'Amsterdam (m. 1720) confesseur de la reine de Pologne e i Minori Capuccini „Italia Francescana" 1936, t. XI, s. 25-27; Rzymskie testamenty królowej Marii Kazimiery spisane w 1713 i 1714 roku, [w:] Źródła do dziejów Sobieskich z Archiwum w Mińsku i zbiorów francuskich, wyd. K. Kossarzecki, Warszawa 2012, s. 104.

${ }^{94}$ Rzymskie testamenty..., s. 104; R. Cord ov a ni, Alessandro Sobieski e i fratti Cappuccini, [w:] I Sobieski a Roma. La famiglia reale polacca nella Citta Eterna, red. J.A. Chrościcki, P. Migasiewicz, Warszawa 2018, s. 217-225. 
Akademii Arkadyjskiej. Poeta w jednym $z$ wersów zapisał, że sznur $z$ jej herbu związal jej duszę $z$ Bogiem poprzez oddane mu uwielbienie $^{95}$.

Najwłaściwsze jest wiązać wykorzystanie sznura w heraldyce wdowiej Marii Kazimiery d'Arquien Sobieskiej z jej ambicjami królewskimi. Wytłumaczmy, że pod tym sformułowaniem kryją się aspiracje do traktowania polskich monarchów elekcyjnych na równych prawach $z$ monarchami dziedzicznymi i włączenia członków ich rodzin - w tym przypadku Sobieskich - do zachodnioeuropejskiego systemu dynastycznego. Marzenia te królowa próbowała realizować już od początku wstąpienia jej męża na tron polski, wykorzystując geopolityczne położenie Rzeczypospolitej. W pewnej mierze wizje te zostały urzeczywistnione dzięki małżeństwom syna królewskiego Jakuba Sobieskiego z Jadwigą Elżbietą z książąt palatynów na Neuburgu w 1691 r., której siostry zasiadały już na europejskich tronach ${ }^{96}$, Teresy Kunegundy Sobieskiej $z$ elektorem bawarskim Maksymilianem Emanuelem Wittelsbachem w 1694 r. ${ }^{97}$ oraz małżeństwom dwóch córek królewicza ${ }^{98}$. Nie przyniosły nato-

95 G.B. Cas a regi, Corona poetica in lode di Maria Casimira Regina Vedova di Polonia, Tessuta della Ragunanza d'Arcadia e recitata avanti la Maestà Sua l'anno 1699, [w:] Raccolta di varii pometti lirici, dramatici, e ditirambici degli Arcadia, Roma 1722 , s. 125.

96 Siostrami Jadwigi Elżbiety były: Maria Zofia (zm. 1748), żona króla Portugalii Piotra II Braganza, Dorota Zofia (zm. 1748), żona Edwarda II Farnese, ks. Parmy i Piacenzy, Maria Anna (zm. 1740), żona króla Hiszpanii Karola II Habsburga. Jej braćmi byli $z$ kolei elektorzy Palatynatu: Filip Wilhelm (zm. 1693), Jan Wilhelm (zm. 1716) i Karol Filip (zm. 1742). Szeroko o udziale Marii Kazimiery d'Arquien Sobieskiej w swatach i zawarciu związku Jakuba Sobieskiego z Jadwiga Elżbieta vide: A. Skrzypietz, Królewscy synowie..., s. 153-181; e a d e m, Jakub Sobieski, Poznań 2015, s. 130-168.

${ }_{97}$ M. Ko ma s zyń s ki, Teresa Kunegunda Sobieska, Warszawa 1982, s. 19-32.

98 Najstarsza $z$ córek Jakuba Sobieskiego i Jadwigi Elżbiety Maria Kazimiera nie wyszła za mąz. Druga z córek Maria Karolina w 1723 r. wyszła za Fryderyka Maurycego de La Tour d'Auvergne ks. de Turenne, a po jego śmierci w 1724 r. za jego brata Karola Gotfryda de La Tour d'Auvergne. Najmłodsza Klementyna poślubiła w 1718 r. pretendenta do tronu angielskiego Jakuba Franciszka Edwarda Stuarta. Więcej o układanych planach matrymonialnych wobec królewien vide: A. Skrzypietz, Wokół małżeństw księżniczek Sobieskich - ze wschodu na zachód Europy, [w:] Staropolski ogląd świata. Rzeczpospolita między okcydentalizmem a orientalizacja. Przestrzeń wyobraźni, red. F. Wolański, R. Kołodziej, t. I, Toruń 2009, s. 246-262; e a d e m, Jakub..., s. 311-333; e a d e m, Propozycje matżeństwa córki królewicza Jakuba Sobieskiego z Karolem XI, [w:] Sic erat in votis. Studia $i$ szkice ofiarowane Profesorowi Zbigniewowi Anusikowi w sześćdziesiata rocznice urodzin. Europa $i$ świat $w$ czasach nowożytnych, red. M. Karkocha, 
miast skutku zabiegi królowej o zeswatanie jej pozostałych synów Aleksandra i Konstantego $z$ francuskimi księżniczkami krwi ${ }^{99}$.

Artykulacji swych zamierzeń Maria Kazimiera szukała także w próbach bezskutecznego wprowadzenia na dwór polski ceremoniału francuskiego ${ }^{100}$. W każdej niemal charakterystyce rodziny królewskiej Maria Kazimiera była portretowana jako osoba wyniosła, skłonna do intryg i oczekująca należnej jej czci ${ }^{101}$. Nieprzychylny królowej Ludwik de Rouvroy de Saint-Simon wspominał nawet, że szybki awans społeczny natchną Marię Kazimierę tak dalece, że zapomniała o swym pochodzeniu i znaczeniu rodziny d'Arquien: „Korona na jej głowie tak niezmiernie ją cieszyła, że jednym jej marzeniem było pokazać ją w swym kraju, który opuściła jako skromna osóbka"102. Owo niedowartościowanie, jak kontynuuje swój wywód pamiętnikarz, było powodem zabiegów Marii Kazimiery o przyznanie jej prawa do zasiadania na taborecie w obecności królowej francuskiej, po jej prawicy, na co nie otrzymała zgody, oraz o wyróżnienia dla swego ojca Henryka d'Arquien w postaci nadania mu Orderu św. Ducha, a następnie kapelusza kardynalskiego. Tych dwóch ostatnich zaszczytów szlachcic dostapił kolejno w 1694 i 1695 r.

O wybujałych ambicjach królowej świadczyły jej zabiegi o uroczysty wjazd do Wiecznego Miasta w marcu 1699 r. w karecie zaprzężonej w sześć koni oraz udzielenie jej pozwolenie na zasiadanie pod baldachimem, na krześle $z$ oparciem w obecności papie-

P. Robak, Łódź 2017, s. 229-241; e a d e m, Plany małżeńskie Sobieskich jako wyraz pozycji rodu - marzenia i rzeczywistość, [w:] Wielkie rody na ziemiach polsko-litewskich w XVI-XX wieku. Wielkie rody-Procesy, red. N. Kasparek, T. Zych, M. Klempert, Olsztyn-Tarnobrzeg 2017, s. 62-67.

${ }^{99} \mathrm{Na}$ ten temat por. A. Skrzypietz, Królewscy..., s. 478-479.

100 J. Pietrzak, Między ceremoniałem a ludycznościa. Codzienność na dworze Jana III Sobieskiego oczami współczesnych mu pamiętnikarzy i korespondentów, [w:] W kregu rodziny epok dawnych - rytmy życia, rytmy codzienności. Dom - codzienność $i$ święto, red. B. Popiołek, A. Chłosta-Sikorska, M. Gadocha, Warszawa 2017, s. 56-72.

101 Warto tu wskazać m.in. [F.D.S.], Dwór Jana III w 1688 i 1689, wyd. J. Siemieński, „Czas. Dodatek miesięczny” 1859, R. IV, t. XIII, s. 463-465; M. Mong rillo n, Pamiętnik sekretarza ambasady francuskiej $w$ Polsce pod koniec panowania Jana III oraz w okresie bezkrólewia i wolnej elekcji po jego zgonie (1694-1698), wyd. Ł. Częścik, Wrocław-Warszawa-Kraków 1984, s. 37-38; B. O’C o n nor, Historia polski, wyd. P. Hanczewski, Warszawa 2012, s. 204.

102 L. de Sain t-Sim on, Pamiętniki, t. II, wyd. A. i M. Bocheńscy, Warszawa 1984, s. $52-53$. 
ża i kardynałów ${ }^{103}$. Zdarzało się, że $z$ podobnych prerogatyw Maria Kazimiera korzystała, przyjmując swych gości podczas audiencji i przy posiłku. Osoby przebywające wówczas w otoczeniu królowej twierdziły, że były traktowane w sposób protekcjonalny i zdystansowany, a monarchini nieustannie pragnęła potwierdzenia swych królewskich splendorów ${ }^{104}$. Wyniosłość monarchini poświadcza wiele innych przykładów z czasów jej przebywania w Rzymie. Wspomnijmy chociażby o wymuszaniu pierwszeństwa przejazdu dla wiozacej ją karety przed ambasadorami państw obcych, m.in. Cesarstwa i Francji, oraz kardynałów ${ }^{105}$ lub zasiadania w czasie uroczystości religijnych na tronie pod baldachimem na trybunie, ustawionej wyżej niż te należące do dyplomatów ${ }^{106}$.

Monarchini, niemal na pewno, czuła się zainspirowana przykładem królowej Krystyny i okresem jej pobytu z przerwami w Rzymie w latach 1655-1689. Przekonuje nas o tym zreszta jeden $z$ listów królowej adresowany do księcia Liwiusza Odescalchiego, w którym obrażona na któregoś ze swoich gości, pytała, czy zachowuje się tak jak szwedzka władczyni ${ }^{107}$. Zgubne próby utożsamienia się z Krystyna, nieznajomość obyczajów i brak orientacji w zasadach ceremoniału sprawiły, że Maria Kazimiera szybko utraciła należny jej majestatowi szacunek. Niewątpliwie decyzja o opuszczeniu Rzymu, choć oficjalnie motywowana koniecznościa poratowania zdrowia $z$ dala od Wiecznego Miasta, wynikała $z$ utraty zainteresowania ludu rzymskiego, arystokracji i samego papieża Klemensa XI sprawami królowej wdowy. Z podobnym „odrzuceniem” Maria Kazimiera spotkała się we Francji. Administracja starała się przyjąć monarchinię $z$ należnym jej szacunkiem, organizując jej triumfalny

103 M. Komaszyński, Maria Kazimiera..., s. 219-225; G. Platania, Gli ultimi Sobieski e Roma. Fasti e miserie di una famiglia reale polacca tra Sei e Settecento (1699-1715), Roma 1989, s. 57-128; G. Vin cen ti, The Exiled Queen Maria Casimira Sobieska in Rome, [w:] Gender, Culture and Politics. Advaces in Gender and Cultural Research in Business and Economics, publ. P. Paolini, R. Lombardi, Rome 2018, s. 3-13; J. Pietrzak, L'ingresso di Maria Casimira d'Arquien Sobieska a Roma nel 1699 e la sua cornice cerimoniale, [w:] I Sobieski..., s. 70-88.

104 Extrait d'une lettre de $\mathrm{M}^{\mathrm{r}}$ le Chevalier de Blatwais première secretaire d'Etat de Sa $\mathrm{M}^{\text {te }}$ Britannique éscrite de Rome, 17 IX 1699, ASCap., ACS, vol. MCXC, karty bez paginacji.

105 Jan Kosmowski do Aleksandra Sobieskiego, Rzym 30 V 1699, BUW, sygn. 76, k. 264r.-265v.

106 M. Loret, Życie polskie w Rzymie w XVIII wieku, Roma 1930, s. 209-210.

107 M.K. d'Arquien Sobieska do Liwiusza Odescalchiego, Frascati 3 XI 1699, ASCap., ACS, busta 1190, fasc. 4, karty bez paginacji. 
pochód do Blois, lecz Ludwik XIV zakazał Marii Kazimierze zbliżania się do Wersalu lub pojawienia się w nim. Królewskie ambicje Marii Kazimiery zostały dotkliwie ograniczone ${ }^{108}$.

Niezależnie od opisanych okoliczności Maria Kazimiera za pomoca używania sznura w swoim herbie próbowała podkreślić więź $z$ domem panującym we Francji. Asumptem do tego, jak przypuszcza Otto Forst de Battaglia, były studia królowej nad genealogia własnej rodziny na podstawie dzieł zebranych w bibliotece męża ${ }^{109}$. Informacji badacza nie potwierdza jednak żadne źródło. Nawet jeśli takie działania zostały podjęte, to musiały zajmować się nimi osoby kompetentne, wyznaczone przez królową. Chciano udowodnić, że Maria Kazimiera nie tylko w warstwie symbolicznej czy też zamysłów politycznych miała prawo do podkreślania swej relacji z Burbonami. Przyglądając się temu zagadnieniu, uznać możemy, że jej daleka przodkini Izabela de la Tour d'Auvergne de Polignac (1400-?) była szwagierka praprawnuka Ludwika IX Świętego Ludwika II ks. de Burbon-Montpensier (zm. ok. 1486) i ciotka hrabiego Owernii i Boulogne Bertranda VI (1417-1494), dziadka Katarzyny Medycejskiej. Sązić można, że to dalekie powinowactwo wystarczyło królowej do zidentyfikowania się z Kapetyngami i ich spadkobiercami. Parantele łączące Marię Kazimierę z Katarzyną Medycejska mogły dostarczyć powodów tej pierwszej do posługiwanie się symbolika sznura. Zapewne też argumentem wspierającym przekonanie Marii Kazimiery o poprawności jej działania był pobyt na zamku w Blois. Pod koniec wieku XV zamek stał się rezydencją królewską ${ }^{110}$. Ostatnie lata swego panowania spędziła w nim Anna Bretońska, która na portalu wejściowym do kaplicy zamkowej umieściła swój monogram, obok cyfry królewskiej Ludwika XII, opleciony sznurem. Ostatnie chwile swego życia spędziła także w Blois Klaudia Francuska w 1524 r. Podobnie rzecz się miała $z$ Katarzyna Medycejską, która dokonała swego żywota w tymże zamku w 1589 r. Z kolei w 1617 r. w Blois, w charakterze aresz-

108 M. Ko ma s zyńs ki, Maria Kazimiera..., s. 221; L. Bély, Louis XIV et la reine Marie-Casimire. Le retour d'une Française ou d'une reine de Pologne?, [w:] I Sobieski..., s. 162-171.

109 O. Forst de Battaglia, Ze studiów genealogicznych nad epoka Jana III Sobieskiego, „Miesięcznik Heraldyczny” 1933, R. XII, nr 9, s. 134, 137-139.

110 M. Ko mas zyń s ki, Maria Kazimiera..., s. 219-223; i d e m, Marie Casimire, reine de Pologne, dernière résidente royale du Château de Blois, Katowice 1995, s. 43-57; id e m, Zamek $w$ Blois - ostatnia rezydencja Marii Kazimiery Sobieskiej (1714-1716), „Przegląd Historyczny” 1978, t. LXIX, z. 2, s. 244-247. 
tantki, osadzona została kolejna francuska królowa wdowa Maria Medycejska, która przebywała w nim do lutego 1619 r. Pamięć o mieszkankach zamku i istnienie kompozycji heraldycznej były ważnym elementem kształtującym wyobrażenie Marii Kazimiery o jej własnej wysokiej pozycji. Dodajmy, że po śmierci królowej regent Francji Filip ks. Orleanu zakazał pochówku ciała polskiej królowej wdowy w miejscowej katedrze, by nie przyrównywać Marii Kazimiery d'Arquien Sobieskiej do jego wielkich poprzedniczek ${ }^{111}$.

Można wysunąć przypuszczenie, że Maria Kazimiera miała wiedzę na temat istnienia w odległej przeszłości Zakonu Sznura i przy ustalaniu swojego nowego herbu kierowała się przesłankami wynikającymi z zadań, jakie ta instytucja pełniła. Sądzić należy, że włączenie sznura przez Marię Kazimierę do swego herbu stanowiło wyraźny przejaw manifestacji jej tożsamości jako Francuzki. O tym, że królowa nie zapomniała o swej ojczyźnie, świadczą jej liczne pobyty we Francji w latach 1648-1652, 1662, 1663, 1668 i 1671, posługiwanie się w korespondencji wyłącznie językiem francuskim oraz podtrzymanie kontaktów $z$ rodzina d'Arquien i de Béthune ${ }^{112}$.

Stwierdzić zatem należy, że wykorzystanie sznura w herbie Marii Kazimiery d'Arquien Sobieskiej było suma kilku motywacji. Po pierwsze, było to świadome nawiązanie do praktyki heraldycznej królowych wdów francuskich i zawarte w tym poszukiwanie - przez wdowę po Janie III - więzi z nimi, w celu włączenia rodziny Sobieskich w krag dynastów europejskich. Po drugie, umieszczenie symbolu o treściach pasyjnych i dewocyjnych było przejawem silnej pobożności królowej i pochwałą ideału wdowieństwa. Po trzecie i ostatnie, była to artykulacja jej odrębności kulturowej i przynależności narodowej.

111 M. Komaszyńs ki, Marie Casimire..., s. 75-77.

${ }^{112}$ M. de Mongrillon odnotował deklarację królowej, która zwierzyła się słowami: „Wiem, że jestem Francuzka i nie zapomnę tego nigdy”. Por. M. de Mongri11o n, op. cit., s. 39. 


\section{Bibliografia}

\section{Ź Ródea ARChiwalne}

Archives nationales de France - site de Paris

Centre de sigillographie et d'héraldique [AnF Centre], sygn. D-48, D-170, D-171, D-171bis, D-173, D-175, D-176, D-177, D-178, D-179, D-180, D-181, D-183, D-10260, D-10261, D-10262, St-4395bis.

Collections iconographiques, sygn. AE/II/3216.

Archivio di Stato di Lucca

Archivio Sardi, sygn. 145.

Archivio di stato di Roma

Fondo Congregazioni Religiosi Benedettine in S. Maria in Campo Marzio, reg. $62,63,64,65,66$.

Archivio Provinciale dei Frati Minori Cappuccini - Roma

Annali manoscritti della Provincia Roma dei Frati Cappuccini (1674), vol. III. Archivio Storico Capitolino w Rzymie [ASCap.]

Archivio Capranica-Scarlatti [ACS], vol. MCLXXXI, MCXC.

Archiwum Główne Akt Dawnych w Warszawie [AGAD]

Archiwum Warszawskie Radziwiłłów (dz. III), sygn. 33.

Zbiory Muzeum Narodowego w Warszawie [ZMN], sygn. 30, 446.

Archiwum Narodowe w Krakowie

Zbiory Rusieckich, sygn. 60.

Biblioteka Książąt Czartoryskich w Krakowie [BCz.]

sygn. 2190/IV, 5885/III, 6770/III.

Biblioteka Uniwersytetu Warszawskiego [BUW]

sygn. 30, 76.

Bibliothèque Municipale w Aix-en-Provence

Ms. 0638.

Bibliothèque nationale de France w Paryżu [BnF]

Ms. Latin 1369, 3027, 9474.

Ms. Français 1993, 5100, 15459, 19088.

Cabinet des médailles, 4480.

Collections iconographiques, sygn. AE/II/3191, AE/II/3216.

Département cartes et planes, sygn. GE D 26179 (RES).

Département éstampes et photographie, sygn. AD-110 (1)-FOL, FOL-QB-201, QB-201 (36)-FOL. 
British Library w Londynie

Mss. Add. 8529.

British Museum

Department of Prints and Drawnings, 1858,0417.1436.

Getty Museum w Los Angeles

sygn. Ms. Ludwig XIII 4, 700719269.

Museum of Fine Arts w Bostonie

sygn. akces. 36.136.

Narodowe Archiwum Historyczne Białorusi w Mińsku

Archiwum Sobieskich z Oławy (f. 695, opis 1), nr 344.

Princton University Library

sygn. 5942.244.12, GA 2005.00584.

Zamek Królewski w Warszawie - Muzeum

Zbiory Tomasza Niewodniczańskiego, sygn. H-25.

\section{STARODRUKI}

Aubert de La Chesnaye-Desbois F.A., Dictionnaire historique des mours, usages, et coutumes des François, t. I, Paris 1768.

Bassani A., Viaggio a Roma della [...] Maria Casimira regina di Polonia vedoua [...] delle [...] Giovanni III per il voto di visitare i Luoghi Santi et il supremo Pastor della Chiesa Innocenzo XII. All' [...] Cardinale Barberino protettore di quel regno. Del Con. Antonio Bassani Padovano Can. di Varmia, Roma 1700.

Crescembeni G.M., Notizie Istoriche degli Arcadi morti, t. III, Roma 1721.

Favin A., Le Théâtre d'honneur et de chevalerie, ou l'histoire des ordres militaires etc., Paris 1610.

Giustiniani Abbé, Histoire des ordres militaires ou des chevaliers des milices etc., t. II, Amsterdam 1721.

Hélyot P., Bullot M., Histoire des ordres monastiques, religieux et militaires etc., Paris 1719.

[Maître des Entrées parisiennes des reines], Entrée de la reine Claude de France à Paris, Paris 1517.

Oronce Fine de Briaville C., Jeu d'Armoires des souverains et estates d'Europe, Lyon 1665.

Prato F., Dizionario storico portatile degli ordini religiosi e militari e delle congregazioni regolari e secolari ch contiente la loro origine, $i$ loro progressi, la loro decadenza, e lei differentia loro riforme, Torino 1742.

Raccolta di varii pometti lirici, dramatici, e ditirambici degli Arcadia, Roma 1722.

Sainte-Marie H. de, Dissertations historiques et critiques sur la chevalerie ancienne et moderne, Paris 1718. 


\section{$\dot{Z}_{\text {RÓDEA DRUKOWANE }}$}

Ciecierski H., Pamiętniki, wyd. T. Ciecierska-Chłapowa, Warszawa 2013.

Mongrillon M. de, Pamiętnik sekretarza ambasady francuskiej $w$ Polsce pod koniec panowania Jana III oraz $w$ okresie bezkrólewia $i$ wolnej elekcji po jego zgonie (1694-1698), wyd. Ł. Częścik, Wrocław-Warszawa-Kraków 1984.

Motteville F. de, Anna Austriaczka i jej dwór, Warszawa 1978.

Saint-Simon L. de, Pamiętniki, t. II, wyd. A. i M. Bocheńscy, Warszawa 1984.

[F.D.S.], Dwór Jana III w 1688 i 1689, wyd. J. Siemieński, „Czas. Dodatek miesięczny" 1859, t. XIII, R. IV, s. 5-48.

Jabłonowski J.S., Traktat o familiach i koligacjach, wyd. M. Górny, Wrocław 2015.

Lettres inédites: Louis XIV, Philippe V, roi d'Espagne, Guillaume III, roi d'Angleterre, Marie-Louise de Savoie, reine d'Espagne, Marie Casimire, reine de Pologne (1680-1714), avec introduction et notes par M. Jametel, Paris 1898.

Livret de l'archiconfrérie du Cordon de Saint-François: origine, obligations, indulgences, cérémonial, diplôme, ed. Société et libr. Saint-François, Paris 1929.

O’Connor B., Historia polski, wyd. P. Hanczewski, Warszawa 2012.

Polonia e Curia Romana. Corrispondenza di Maria Kazimiera Sobieska regina di Polonia, con Carlo Barberini prottetore del regno (1681-1699) e il soggiorno romano di una famiglia polacca in esilio, a cura di G. Platania, Viterbo 2016.

Sigilla Regum et Reginarum Poloniae. Pieczęcie królów i królowych polskich ze zbiorów Archiwum Głównego Akt Dawnych, wyd. Archiwum Główne Akt Dawnych i Naczelna Dyrekcja Archiwów Państwowych, Warszawa 2015.

Źródła do dziejów Sobieskich z Archiwum w Mińsku i zbiorów francuskich, wyd. K. Kossarzecki, Warszawa 2012.

\section{OpRacowania}

Bergin J., Anne d'Autriche et les dévots, [w:] Anne d'Autriche. Infante d'Espagne et reine de France, dirigé Ch. Grell, Paris 2009, s. 187-209.

Bély L., Louis XIV et la reine Marie-Casimire. Le retour d'une Française ou d'une reine de Pologne?, [w:] I Sobieski a Roma. La famiglia reale polacca nella Citta Eterna, red. J.A. Chrościcki, P. Migasiewicz, Warszawa 2018, s. 162-171.

Bosseboeuf L.A., Château et la Sainte-Chapelle de Champigny-sur-Veude (Indreet-Loire), notice historique et archéologique, Tours 1881.

Brejon de la Vergnee J., L'emblématique d'Anne de Bretagne d'après les manuscrits à peinture, „Mémoires de la Société d'Histoire et d'Archéologie de Bretagne” 1978, t. LV, s. 83-97.

Brown C.J., Claude de France: In her Mother's Likeness a Queen with Symbolic Clout?, [w:] The Cultural and Political Legacy of Anne de Bretagne. Negotiating Convention in Books and Documents, pub. D.S. Brewer, Cambridge 2010, s. $123-144$.

Brown J., The Queen's Library. Image-Making at the Court of Anne of Brittany, 1477-1514, Philadelphie-Oxford 2011. 
Conihout I. de, Ract-Madoux P., Veuves, pénitents et tombeaux. Reliures françaises funèbres, Catherine de Médicis et Henri III, [w:] Les funérailles à la renaissance: $X I I^{e}$ colloque international de la Société française d'étude du seizième, sous le direction de J. Balsamo, Genève 2002, s. 225-268.

Cordovani R., Alessandro Sobieski e i fratti Cappuccini, [w:] I Sobieski a Roma. La famiglia reale polacca nella Citta Eterna, red. J.A. Chrościcki, P. Migasiewicz, Warszawa 2018, s. 217-225.

Delepierre J.O., Notice sur la cheminée de la salle des magistrats du Francs de Bruges, Bruges 1841.

Dupuy A., Histoire de l'Union de la Bretagne à la France, Paris 1880.

Forst de Battaglia O., Ze studiów genealogicznych nad epoka Jana III Sobieskiego, „Miesięcznik Heraldyczny” 1933, R. XII, nr IX, s. 132-141.

Gach P., Habity zakonne w średniowieczu. Zarys problematyki, [w:] Klasztor w kulturze średniowiecznej Polski, red. A. Pobóg-Lenartowicz, M. Derwich, Opole 1995, s. 491-516.

Gady A., Anne d'Autriche et Paris, [w:] Anne d'Autriche. Infante d'Espagne et reine de France, dirigé Ch. Grell, Paris 2009, s. 295-323.

Gaethgens B., Les portraits d'Anne d'Autriche. L'image royale au service de la politique, [w:] Anne d'Autriche. Infante d'Espagne et reine de France, dirigé Ch. Grell, Paris 2009, s. 209-243.

Grodecki L., Callias Bey M., Perrot F., Les Vitraux du Centre et des Pays de la Loire, [w:] Corpus vitrearum, Éditions du Centre National de la Recherche Scientifique, Paris 1981, s. 1-36.

Hablot L., Pour en finir ou pour commencer! - avec l'ordre de la Cordelière, [w:] Pour en finir avec Anne de Bretagne, ed. D. Le Page, Nantes 2004, s. 47-70.

Hablot L., Les princesses et la devise. L'utilisation politique des devises et des ordres de chevalerie par les femmes de pouvoir à la fin du Moyen Age, [w:] Femmes de pouvoir et pouvoir de femmes dans l'Occident, eds A. Nayt-Dubois, E. Satninelli-Foltz, Valenciennes 2009, s. 163-183.

Henderson V.K., Rethinking Henry VII: The Man and His Piety in the Context of the Observant Franciscans, [w:] Reputation and Representation in Fifteenth-Century Europe, eds D.L. Biggs, S.D. Michalove, Leiden 2004, s. 317-349.

Hildebrand P., Le père Louis d'Amsterdam (m. 1720) confesseur de la reine de Pologne e i Minori Capuccini „Italia Francescana” 1936, t. XI, s. 373-376.

Hochner N., Louis XII and the porcupine: transformations of a royal emblem, „Rennaisance Studies" 2001, vol. XV, no. 1, s. 17-36.

Jones M., Les signes du pouvoir. L'ordre de l'Hermine, les devises et les hérauts des ducs de Bretagne au XVe siècle, „Mémoires de la Société d'histoire et d'archéologie de Bretagne” 1991, t. LXVIII, s. 141-173.

Kapellari E., Święte znaki w liturgii i codzienności, Kraków 2002.

Komaszyński M., Maria Kazimiera Sobieska d'Arquien Sobieska, królowa Polski (1641-1716), Kraków 1983.

Komaszyński M., Marie Casimire, reine de Pologne, dernière résidente royale du Château de Blois, Katowice 1995. 
Komaszyński M., Piękna królowa Maria Kazimiera d’Arquien-Sobieska, 1641-1716, Warszawa 1995.

Komaszyński M., Teresa Kunegunda Sobieska, Warszawa 1982.

Komaszyński M., Zamek $w$ Blois - ostatnia rezydencja Marii Kazimiery Sobieskiej (1714-1716), „Przegląd Historyczny” 1978, t. LXIX, z. 2, s. 239-260.

Labande-Mailfert Y., Le mariage d'Anne de Bretagne avec Charles VIII, vu par Erasme Brasca, „Mémoires de la Société d'histoire et d'archéologie de Bretagne” 1978, t. LV, s. 17-42.

Lecoqe A.-M., François Ier. Imaginaire, symbolique et politique à l'aube de la Renaissance française, Paris 1987.

Loret M., Życie polskie w Rzymie w XVIII wieku, Roma 1930.

Łoski J., Jan Sobieski, jego rodzina, towarzysze broni i współczesne zabytki, Warszawa 1883.

Magdziarz W.S., Anna Austriacka, Warszawa 2013.

Mazel C., À corps et à cours: les monuments funéraires des Valois, 1461-1589, [w:] Les Funérailles princières en Europe XVI $-X V I I I^{e}$ siècle, t. II (Apothéoses monumentales), sous les direction de J.A. Chrościcki, M. Hengerer, G. Sabatier, Versailles 2013, s. 229-243.

Merindol C. de, Essai sur l'emblématique et la thématique de la maison de Bretagne. Mise au point, nouvelles lectures, nouvelles perspectives, [w:] 1491. La Bretagne, terre d'Europe, publ. J. Kerhervé, T. Daniel, Brest-Quimper 1992, s. $187-227$.

Nassiet M., Les reines héritères: d'Anne de Bretagne à Marie Stuart, [w:] Femmes et pouvoir politique. Les princesses d'Europe $X V^{e}-X V I I I^{e}$ siècle, sous le direction d'Isabelle Poutrin, M.-K. Schaub, Bréal 2007, s. 134-143.

Nassiet M., La Page D., L'union de la Bretagne à la France, Morlaix 2003.

Noël F.-J.-M., Nouveau dictionnaire des origines, inventions et découvertes, t. I, Paris 1827.

Paoleti M., Il Nodo: Storia, Mitologia e Misteri del simbolo più antico dell'umanità, Firenze 2015.

Pietrzak J., L'ingresso di Maria Casimira d'Arquien Sobieska a Roma nel 1699 e la sua cornice cerimoniale, [w:] I Sobieski a Roma. La famiglia reale polacca nella Citta Eterna, a cura di J.A. Chrościcki, Z. Flisowska, P. Migasiewicz, Warszawa 2018, s. 70-90.

Pietrzak J., Między ceremoniałem a ludycznościa. Codzienność na dworze Jana III Sobieskiego oczami współczesnych mu pamiętnikarzy i korespondentów, [w:] W kregu rodziny epok dawnych - rytmy życia, rytmy codzienności. Dom - codzienność $i$ święto, red. B. Popiołek, A. Chłosta-Sikorska, M. Gadocha, Warszawa 2017, s. 56-73.

Platania G., Gli ultimi Sobieski e Roma. Fasti e miserie di una famiglia reale polacca tra Sei e Settecento (1699-1715), Roma 1989.

Rìo Barredo M.J. del, Enfance et éducation d'Anne d'Autriche à la cour de Espagne (1601-1615), [w:] Anne d'Autriche. Infante d'Espagne et reine de France, dirigé Ch. Grell, Paris 2009, s. 11-41. 
Riviale L., Les verrières de la Sainte-Chapelle de Champigny-sur-Veude (Indreet-Loire), [w:] Congrès archéologique de France. $155^{e}$ session. Monuments en Touraine, ed. Société Française d'archéologie, Paris 2003, s. 55-76.

Rosińska D., Jana Sobieskiego życie religijne, [w:] Z dziejów XVII i XVIII wieku. Ksiega jubileuszowa ofiarowana Profesorowi Michałowi Komaszyńskiemu, red. J. Kwak, Katowice 1997, s. 65-84.

Rotter L., Habit franciszkański na przykładzie wybranych wspólnot męskich i żeńskich, „Zeszyty Sądecko-Spiskie” 2009, t. IV, s. 66-73.

Santrot H., Entre France et Angleterre, le duché de Bretagne, essai d'iconographie des ducs de Bretagne, Nantes 1988.

Skrzypietz A., Infant Jan, czyli ostatni królewski pogrzeb na Wawelu, [w:] W podró$\dot{z} y$ przez wiek osiemnasty. Studia $i$ szkice $z$ epoki nowożytnej, red. A. Perłakowski, M. Wyszomirska, M. Zwierzykowski, Kraków 2015, s. 71-91.

Skrzypietz A., Jakub Sobieski, Poznań 2015.

Skrzypietz A., Królewscy synowie - Jakub, Aleksander i Konstanty Sobiescy, Katowice 2011.

Skrzypietz A., Plany małżeńskie Sobieskich jako wyraz pozycji rodu - marzenia i rzeczywistość, [w:] Wielkie rody na ziemiach polsko-litewskich w XVI-XX wieku. Wielkie rody - Procesy, red. N. Kasparek, T. Zych, M. Klempert, OlsztynTarnobrzeg 2017, s. 52-72.

Skrzypietz A., Propozycje małżeństwa córki królewicza Jakuba Sobieskiego z Karolem XI, [w:] Sic erat in votis. Studia i szkice ofiarowane Profesorowi Zbigniewowi Anusikowi w sześćdziesiata rocznice urodzin. Europa $i$ świat $w$ czasach nowożytnych, red. M. Karkocha, P. Robak, Łódź 2017, s. 229-243.

Skrzypietz A., Wokót małżeństw księżniczek Sobieskich - ze wschodu na zachód Europy, [w:] Staropolski ogląd świata. Rzeczpospolita między okcydentalizmem a orientalizacją. Przestrzeń wyobraźni, red. F. Wolański, R. Kołodziej, t. I, Toruń 2009, s. 246-262.

Surgers A., Les images du règne. Le roi nous regarde, [w:] François $I^{e r}$ pouvoir et image, sous le direction de B. Petey-Girard, M. Vène, Paris 2015, s. 66-77.

Tomaszewski N., Tomaszewska O., Dokumenty zwiazane ze szlachta $w$ zbiorach Muzeum Rolnictwa im. Ks. Krzysztofa Kluka w Ciechanowcu, „Ciechanowiecki Rocznik Muzealny" 2007, t. III, s. 11-19.

Tourault P., Anne de Bretagne, Paris 2014.

Tourault P., Les ducs et duchesses de Bretagne, $X^{e}-X V I^{e}$ siècle, Paris 2009.

Viennot E., Veuves de mère en fille au XVIe siècle: le cas du clan Guise, [w:] Veufs, Veuves et veuvage dans la France d'Ancien-Régime, sous le direction N. Pellegrin, C. Winn, Paris 2003, s. 187-198.

Vilain-De Bruyne A., Le cachet de Catherine de Médicis. Une matrice réginale inédite, „Revue de la Bibliothèque nationale de France” 2013, no. 43, s. 74-78.

Vincenti G., The Exiled Queen Maria Casimira Sobieska in Rome, [w:] Gender, Culture and Politics. Advances in Gender and Cultural Research in Business and Economics, publ. P. Paolini, R. Lombardi, Rome 2018, s. 3-11.

Walicka I.M., Kościół i klasztor Sakramentek w Warszawie. Pomnik Zwycięstwa pod Wiedniem, Warszawa 1988. 
Widacka H., Zagadki portretu królowej Marii Kazimiery w diariuszu Antonia Bassaniego, „Studia Wilanowskie” 2009, t. XVI, s. 108-113.

Wilson-Chevalier K., "Trinités royales" et "quadrangle d'amour": Claude de France. Marguerite de Navarre, François $I^{e r}$, Louise de Savoie et le réforme fabriste de l'Église, [w:] "La dame de coeur". Patronage et mécénat religieux des femmes de pouvoir dans l'Europe des XIVe-XVII siècles, sous le direction de M. GaudeFerragu, C. Vincent-Cassy, Rennes 2006, s. 123-137.

\section{Netografia}

http:/ / ombresdemeslivres.wifeo.com/mlle-de-blois-duchesse-d-orleans.php (dostęp: 19 III 2017).

http: / passion-heraldique.blogspot.com/2012/12/armorial-du-parlement-de-quebec-6e.html (dostęp: 19 III 2017).

http:/ / patrimoine-de-france.com/seine-et-marne/jouarre/abbaye-notre-dame-de-jouarre-1.ph (dostęp: 14 III 2017).

http://sceau.hypotheses.org/627 (dostęp: 17 III 2017).

http: / / www.ande.fr / DetailElement.aspx?numStructure=78849\&numElement =76997 (dostęp: 19 III 2017).

http:/ / www.anticstore.com/plaque-cheminee-decoree-un-blason-cordeliere-22823P (dostęp: 19 III 2017).

http:/ /www.bibliophilie.blogspot.com/2012/11/miscellanees-dubibliophile-bredouille.html (dostęp: 19 III 2017).

http: / www.bibliotheque-conde.fr/expositions / histoire-de-la-reliure/reliuresaux-armes-des-seigneurs-de-chantilly-xvie-xixe-siecle/ (dostęp: 19 III 2017).

http://www.freres-capucins.fr/Saint-Francois-et-le-Christ-aux.html (dostęp: 13 IV 2017).

https://en.wikipedia.org/wiki/Catherine_Henriette_de_Bourbon\#/media/File:Catherine_Henriette_de_Bourbon,_Légitimée_de_France,_1659.jpg (dostęp: 19 III 2017).

Jarostaw Pietrzak

\section{The rope in heraldry of the queen dowager Maria Kazimiera d'Arquien Sobieska}

$\mathrm{T}$ he work concerns on heraldic-genealogical element, which was the Franciscan string from the coat of arms of the queen dowager Marie Casimire d'Arquien Sobieska, omitted in the previous studies. The first part disscused the traditions of its applicability dating back to the fifteenth century and the circle of the Breton Dukes' court. It also shows the establishment of this tradition in the heraldry of the Kapetin dynasty and its two branches - Valois and Bourbons. A process was presented, according to which the string from the personal emblem associated with the dukedom in Brittany transformed into an element symbolizing 
the widowship of the queens of France. Then, in the seventeenth century the string became the signe of widows from the aristocratic sphere. Here are given the arguments of heraldry exhibited on seals, medals, portraits engravings and objects of everyday use, for example the books covers. In the second part, were considered the reasons why Marie Casimire Sobieska joining to her coat of arms the symbol of a Franciscan string. Her actions were recognized as a conscious creation, aiming to exalt her majesty after 1696 and to emphasize the relationship with the royal house of France.

Keywords: heraldry, widowhood, Sobieski family, France. 